No. 19-9

\title{
Trends in Household Portfolio Composition
}

\author{
Jesse Bricker, Kevin B. Moore, and Jeffrey Thompson
}

\begin{abstract}
:
We use data from the Federal Reserve Board's Survey of Consumer Finances (SCF) to explore how household asset portfolios in the United States evolved between 1989 and 2016. Throughout this period, two key assets - housing and financial market assets - drove the household balance sheet evolution; however, we find a great heterogeneity in the balance sheets that averages and aggregates conceal. We observe that ownership of assets has become more concentrated over time, and we show that nearly all of the time series variation in financial vulnerabilities in family balance sheets is due to middle-income families, who hold most of their assets in housing and are often the most highly leveraged income group in the housing market. Tracking the evolution of wealth over time among birth-year cohorts, we observe the standard life-cycle asset accumulation processes among low-, middle-, and high-income families.
\end{abstract}

\section{JEL Classifications: D31, G11, D14, E21, E22, G51}

Keywords: portfolio composition, asset inequality, life-cycle savings patterns, financial risk

Jesse Bricker is a principal economist with the Board of Governors of the Federal Reserve System; his email is jesse.bricker@frb.gov. Kevin B. Moore is chief of the Microeconomic Surveys Section in the Board's Division of Research and Statistics; his email is kevin.b.moore@frb.gov. Jeffrey Thompson is a senior economist and policy advisor in the Research Department at the Federal Reserve Bank of Boston, where he is the director of the New England Public Policy Center. His email is jeffrey.thompson@bos.frb.org.

A version of this paper is included as Chapter 3 in Handbook of US Consumer Economics $1^{\text {st }}$ edition, 2019, edited by Andrew Haughwout and Benjamin Mandel, 53-96. Cambridge, MA: Academic Press.

The authors thank Kathy Bi and Peter Hansen for excellent research assistance. They also thank their colleagues on the SCF project who helped make this research possible: Neil Bhutta, Lisa Dettling, Joanne Hsu, Elizabeth Llanes, Sarah Pack, John Sabelhaus, and Richard Windle. They greatly benefited from the comments of the editors of Handbook of US Consumer Economics, Andrew Haughwout and Benjamin Mandel, and other authors in this volume. They thank Michael Haliassos and seminar participants at the European Central Bank and the Federal Reserve Board for their comments. They are also grateful for coordination with the staff at the Statistics of Income, especially Barry Johnson, David Paris, Michael Parisi, Lori Hentz, and Lisa Russ.

This paper presents preliminary analysis and results intended to stimulate discussion and critical comment. The views expressed herein are those of the authors and do not indicate concurrence by the Federal Reserve Bank of Boston, the principals of the Board of Governors, or the Federal Reserve System. This paper, which may be revised, is available on the website of the Federal Reserve Bank of Boston at https://www.bostonfed.org/publications/researchdepartment-working-paper.aspx.

This version: September 2019

https://doi.org/10.29412/res.wp.2019.09 


\section{Introduction}

Understanding the composition and distribution of household balance sheets - and how the two have evolved over time-is important for a host of economic policies. The allocation of assets and debts will influence household exposure to unexpected economic shocks (Mian, Rao, and Sufi 2013) and the preparedness of the current workforce for future retirement (Henriques et al. 2018); portfolio composition also has implications for the transmission of monetary and fiscal policy (Mian, Rao, and Sufi 2013; Benmelech, Miesenzahl, and Ramcharan 2017; Poterba and Samwick 2003), and it can influence the future path of wealth and income inequality (Piketty 2013; Stiglitz 2012).

In this paper, we use data from the Federal Reserve Board's Survey of Consumer Finances (SCF) to explore how household asset portfolios in the United States evolved between 1989 and 2016. Overall, household assets grew from about $\$ 25$ trillion in 1989 to slightly more than $\$ 100$ trillion in 2016. Because the aggregated wealth and asset data in the SCF are consistent with information from the Financial Accounts of the United States (FA), the National Income and Product Accounts (NIPA), and other macroeconomic data sources (Dettling et al. 2015), we can use the SCF to better understand the distribution of aggregate US household assets. ${ }^{1}$

Throughout the 1989-2016 period, two key assets - housing and financial market assetsdrove the household balance sheet evolution. The relative importance of housing and financial market assets has fluctuated over time. Between 1989 and 2001, financial market assets became more prevalent in the household portfolio as the number of retirement accounts - such as IRAs and workplace 401(k)s - increased across families, and defined-benefit (DB) retirement plans faded. Between 2001 and 2007, increases in house values and the homeownership rate pushed the share of assets in housing higher, whereas the fall in the homeownership rate and the rise of financial markets between 2010 and 2016 boosted the share of financial assets.

However, we also find a great heterogeneity in household balance sheets that averages and aggregates conceal. For example, in 2016, though housing made up about 30 percent of the average household asset portfolio, and financial market assets made up about 40 percent, most

\footnotetext{
${ }^{1}$ The SCF captures the entire balance sheet, but in this paper we focus primarily on assets. We use "portfolio" to refer to all types of assets, both financial and non-financial.
} 
families held a relatively small share of assets in financial markets and instead held primarily housing assets. Families near the median held about 60 percent of assets in housing and only 20 percent in financial markets. The asset portfolio of the average household most closely resembled families near the 90th percentile of assets.

We also observe that ownership of assets has become more concentrated over time. Increased concentration is seen within the distribution of assets and the distribution of income and by age. Since the processes that create wealth for a household unfold over time, the relationship between assets and age can be complicated. We explore the trends in asset levels and portfolio composition over the life cycle later in this paper using a birth-year/income-group cohort analysis of the SCF.

We observe the typical life-cycle asset accumulation processes among low-, middle-, and high-income families. Though the levels are of different magnitudes, assets generally increase throughout the typical working life for each of the three income groups, and they peak just before the typical retirement age. Afterward, assets decumulate, but only partly. We also observe movement out of "risky" assets (asset classes that are especially exposed to asset-price shocks), particularly businesses and equities, as household heads transition into retirement. Homeownership remains high through the household heads' early eighties, the age of the oldest cohorts when they are observed for the final time. The housing share of total assets actually rises in retirement, as families remain in their homes and start to consume out of their other assets.

Finally, we focus on quantifying financial vulnerabilities in family balance sheets. We first show that the number of families with a combination of two potential vulnerabilities - high debt payments and a high loan-to-value ratio on their primary residence - peaked in the late 2000s and in 2016 was at its lowest level since the early 1990s. We also show that nearly all of the time series variation is due to middle-income families, who hold most of their assets in housing and are often the most highly leveraged income group in the housing market.

\section{SCF Data and Comparison to Aggregates}

The SCF is a cross-section survey conducted every three years by NORC at the University of Chicago on behalf of the Federal Reserve Board and with the cooperation of the Department of Treasury. ${ }^{2}$ The SCF provides the most comprehensive and highest quality survey microdata

\footnotetext{
${ }^{2}$ See Bricker et al. (2017) for results from the 2016 SCF.
} 
available on US household wealth. SCF families respond to questions about financial and nonfinancial assets, debts, employment, income, and household demographics.

Due to the concentrated nature of wealth, a random sample of US families is unlikely to capture the small minority of families who hold the large majority of wealth. Wealthy families are also less likely to participate in a survey; thus, a random sample of families may incorrectly estimate the mean and variance of wealth. The SCF provides unbiased and efficient estimates of the distribution of household wealth by using a dual-frame sample design in which a nationally representative set of families selected from an address-based frame (the "area probability" sample) is supplemented with an oversample of wealthy families selected from administrative records derived from income tax returns (the "list" sample).

The area probability sample provides a nationally representative sample of families. ${ }^{3}$ Of the 6,000 families surveyed in the $2016 \mathrm{SCF}$, about 1,500 are from the list sample. No administrative data are directly associated with measuring the cross-section of wealth at a point in time. ${ }^{4}$ Therefore, selecting the list sample depends on inferring wealth from administrative records derived from income tax returns - the Individual and Sole Proprietor (INSOLE) data file maintained by SOI (Statistics of Income 2012). ${ }^{5}$ The INSOLE file is a sample of tax filings from the IRS administrative tax data that are statistically edited for quality by SOI. In the list sampling process, wealth is inferred from these income records through two models that relate wealth to income. ${ }^{6}$

\footnotetext{
${ }^{3}$ See Tourangeau et al. (1993) and O'Muircheartaigh, Eckman, and Weiss (2002) for more information on the area probability sample selected by NORC staff.

${ }^{4}$ The only official wealth record that exists in the United States comes from an estate tax. This tax is applied at death and only to families with estates greater than $\$ 5$ million (since the mid-2000s).

${ }^{5}$ The INSOLE file consists of a sample of individual and sole proprietorship tax filings from the IRS administrative tax data, statistically edited for quality by SOI. Tax filings with unique income are oversampled, and many highincome records in the INSOLE file are sampled with certainty (Statistics of Income 2012). The INSOLE file is a sample of the IRS administrative tax data, so the list sample is a sample from a sample. No correction for this is made during the LS sampling procedure, though, because the certainty sample and rare incomes found in the INSOLE file are a near certainty sample of the LS target population (Kennickell and Woodburn 1999). The unit of observation in the INSOLE data is a tax unit, while the SCF unit of observation is a family. In practice, there are millions more tax units than families, because several members of a family can file distinct tax returns; without a correction, these multi-filer families would have a disproportionately large chance of being selected. To account for this in the SCF LS sampling process, the INSOLE sampling weight of tax units that filed "married filing separately" is divided in half. Further, all filers below the age of 18 are dropped (a family headed by someone younger than age 18 is ineligible for the SCF). Still, to a certain extent, the discrepancy between tax units and families remains in the adjusted INSOLE sampling frame.

${ }^{6}$ See Bricker, Henriques, and Moore (2017) for more detailed information on SCF sampling.
} 
The SCF not only oversamples wealthy families but also ensures adequate response rates through careful fieldwork (Kennickell 2008). Response rates for list sample families range from about 35 percent (for families near the $99^{\text {th }}$ percentile of the wealth distribution) to about 10 percent for the very wealthiest families (the $99.9^{\text {th }}$ percentile). These response rates are constructed before the field period begins and should not be taken as evidence that differential non-response biases the upper-end estimates in the SCF. In fact, high-end families who respond to the SCF are observably similar to those who do not respond (Bricker et al. 2016).

The SCF area probability and list families are woven together by a set of sample weights (Kennickell and Woodburn 1999; Kennickell 1999). In each sample, the base sampling weight is adjusted to account for non-response, population targets, and the strengths of each sample. Overall, the sampling and weighting mechanisms serve to select a set of high-wealth tax filers and fit those families into a set of US families.

\section{Wealth Measurement: Comparing the SCF to Macro Aggregates}

A test of the success of the SCF sample design compares aggregate assets and debts measured in the SCF with those measured in other data sources used to track the macroeconomy - including the Financial Accounts of the United States (FA). Some conceptual measurement differences between the SCF and the other sources make a direct comparison inappropriate; however, once these concepts are put into comparable terms, the SCF and the other data sources produce very similar aggregate measures (Henriques and Hsu 2014; Dettling et al. 2015).

Notably, the SCF asset measure used in this paper does not measure the family's implied asset claims for defined-benefit (DB) pensions, while national wealth measured in the FA does include DB pension wealth. After we adjust the FA measure to exclude DB pension wealth, the level and trend in aggregate total financial assets in the SCF are similar to those in the FA (Figure 1). Various other studies have added DB pension wealth to the SCF measure of wealth; those studies find that families in the upper-middle part of the wealth distribution claim DB pension wealth (Devlin-Foltz, Henriques, and Sabelhaus 2016; Henriques et al. 2018; Bricker et al. 2016).

The primary differences across the two sources are the greater business assets and housing values found by the SCF (Figure 1). Since real estate holdings account for a large portion of 
non-corporate business assets, the differences in both categories are linked to real estate. In the case of housing values, the SCF relies on self-reports by homeowners, whereas the FA used housing wealth from the American Housing Survey (AHS) through the mid-2000s, and since then it has been updated by repeat-transaction house price indices. The surveys' divergence in real estate assets dates to the FA's adoption of this change in methodology. If the aggregate housing values in the FA data were calculated instead by using Zillow's AVM model, the SCF and FA values would be much closer to each other (Gallin et al. 2018). This shows that the current FA methodology may lead to an underestimate of housing assets in the United States and that aggregate asset valuations can potentially differ considerably across data sources.

\section{The SCF and Other Household Finance Research}

As more attention is paid to household finance, the SCF is often the source for household balance sheet information in the United States (Campbell 2006). The SCF has been used to examine the impact of the Great Recession on the balance sheets of young people (Dettling and Hsu 2014), mortgage borrowing leading up to the Great Recession (Foote, Lowenstein, and Willen 2016), entrepreneurship and asset diversification (Moskowitz and Vissing-Jorgensen 2002; Cagetti and Di Nardi 2006), the marginal propensity to consume (Carroll, Slacalek, and White 2017), precautionary saving (Cagetti 2003), and the equity participation puzzle (Bertaut and Starr-McCluer 2001; Haliassos and Bertaut 1995), among other issues.

\section{Composition of Average Household Portfolios}

Households can hold two main types of assets: financial, such as those held at depository institutions and brokerages, and non-financial, such as housing and businesses. Throughout the 1989-2016 sample period, nearly all families owned assets of some kind (Table 1). Early in the sample period, the ownership rate for each main type of asset was about 90 percent; by the end of the period, financial assets were more widely held than non-financial assets. Throughout this section, we use averages to describe how household portfolios changed between 1989 and 2016.

Mean asset holdings in the early part of the sample period (1989 through 1995) were about $\$ 375,000$ (in 2016 dollars) (Table 2). In total, financial assets accounted for about 30 percent of the aggregate household balance sheet at that time (represented by the gray striped areas in Figure 2), and non-financial assets were about 60 percent of the total (the solid gray areas in Figure 1). The remaining "other" assets_-such as vehicles, cash-balance life insurance, and 
savings bonds - were about 10 percent of the total. Average debt levels were about $\$ 52,000$, and about three-quarters of total debt owed was in the form of mortgage debt. Though the balances were smaller, credit card debt and vehicle debt were widely owed by families at the time, too.

Mean real assets grew 50 percent between the early sample period and the 1998-2001 period. Financial assets led the growth; they became almost 40 percent of assets (Figure 2), up from about 30 percent in the previous period. Financial asset growth was led by directly held financial market assets (such as stocks, bonds, and mutual funds) and indirectly held financial market assets intended for retirement (such as IRAs and 401(k)-type pension plans). ${ }^{7}$

The growth in directly held and indirectly held financial market assets occurred at both the intensive and extensive margins, and for voluntary and involuntary reasons. At the intensive margin, the mean values of financial market and retirement accounts more than doubled from the earlier period (Table 2), reflecting the rise in the value of publicly traded equities. At the extensive margin, the share of families who owned equity-directly or through a retirement account-grew from about 35 percent to 50 percent (Table 1). Part of the growth at the extensive margin was due to families entering the financial markets through employer-sponsored defined-contribution (DC) pension plans, such as 401(k)s. DC pension plans became popular enough during the 1990s for employee coverage by these plans to overtake coverage by definedbenefit (DB) pensions. ${ }^{8}$ But families also entered the equity markets by purchasing equities directly — nearly 30 percent of families had done so by 2001, up from 20 percent in the early observation period — and through self-directed retirement accounts (IRAs). The 2001 peak in equity ownership coincided with the end of the "dot-com bubble," the stock market correction of 2000 and 2001, and the 2001 recession.

The mean value of housing assets also increased during the 1998-2001 period (Table 1), as homeownership rates and mean home values both rose (Table 2). Housing debt grew, too: Compared with the earlier period, 10 percent more families owed mortgage debt, and mortgage debt levels grew about 25 percent. The growth in mortgage debt pushed total debt about 25 percent higher.

\footnotetext{
${ }^{7}$ The other group of financial assets are bank-type assets (such as checking and saving accounts and CDs).

${ }^{8}$ Part of this increase in household assets, then, was due to a previously off-the-books asset entering the household balance sheet.
} 
In the 2004-2007 period, the real value of average household assets again rose about 50 percent, though this time house-price increases drove the growth. The homeownership rate continued to increase after the 2001 recession, peaking in 2004 at more than 69 percent and remaining near that level through 2007. As house prices increased between 2004 and 2007, more families enjoyed the asset price increase; for both of these reasons, housing became the dominant asset on household balance sheets. During the 2004-2007 period, about 40 percent of household assets were in the form of housing.

Along with the increase in housing assets was an increase in mortgage debt (Tables 1 and 2). Relative to the 2001-2004 period, about 10 percent more families owed mortgage debt -48 percent of families now held a mortgage - and the real value of average mortgage debt increased 50 percent-from $\$ 52,000$ to $\$ 80,000$. The increase in mortgage debt was partly due to an influx of new entrants in the housing market, and also to repeat buyers and cash-out refinancing. Other debts, though, were still widely held at the time, especially through credit cards and vehicle loans.

During the 2004-2007 period, the average values of financial market and retirement assets remained near their 1998-2001 levels, but it shrank as a share of the balance sheet. The share of families directly holding financial market assets fell, but the share of families holding any type of equity remained at about 50 percent (Table 1).

House values and the homeownership rate began falling at the end of the 2004-2007 period, and by 2010 house prices had also fallen, 25 percent on average, from the 2006 market highs. Equity markets also experienced a 15 percent decline. Overall, mean asset values fell about 15 percent between the 2007 and 2010 surveys.

As the US economy recovered during the 2013-2016 period, the real value of assets grew about 25 percent (Table 2). Though the equity market began a recovery in 2010, house prices did not increase until about 2013. Financial assets again accounted for almost 40 percent of total assets (Figure 2), and housing as a share of assets was just over 30 percent, the lowest level in the 1989-2016 period. The real value of equities, businesses, and housing increased. However, because the homeownership rate continued to fall—to less than 64 percent by 2016 - few families benefitted from the recovery in house prices. 
Between 2010 and 2013, though, both the fraction of families with debt and average debt balances declined. This decline is observed across nearly all debt types, except student loans. The fraction of families with mortgages fell from 49 percent to 43 percent; the fraction revolving credit card debt fell from 46 percent to 38 percent; and the fraction with other debt remained at about 50 percent. Average real debt balances fell about 10 percent between 2010 and 2013, led by declines in mortgage, other residential, and credit card debt; average balances of other forms of debt increased about 1 percent.

Between 2013 and 2016, however, the fraction of families with any debt increased markedly, to 77 percent — rising above the previous peak from 2007—despite the continued decline in the fraction of families with mortgage debt (down to 42 percent). The fraction revolving credit card debt climbed to nearly 44 percent, and the fraction with other forms of debt rose to 52 percent—led by vehicle and education debt—its highest value since 1989. Real debt balances rose about 1 percent despite a 5 percent decline in mortgage debt (to $\$ 66,000$, on average). Average real credit card debt rose 11 percent, and other debt increased 26 percent.

\section{Household Portfolios across the Asset Distribution}

Though the average household asset portfolio is a mix of housing and financial market assets, the main asset for most families is housing, with financial market assets representing a relatively small portion of the portfolio. In fact, because asset holdings are highly concentrated at the top of the asset distribution, much of the change in the aggregate portfolio is driven by asset changes in the top 10 percent of the asset distribution.

Figure 3 shows the asset composition of households at various points in the asset distribution and the average asset composition in 2016. The most noticeable feature is how much asset portfolios vary across the distribution. Housing is the most common asset for most families, except those in the top 1 percent of the asset distribution; they hold mostly private equity in businesses and financial market assets. ${ }^{9}$

\footnotetext{
${ }^{9}$ The composition of assets across the US asset distribution is remarkably similar to the composition in Sweden (Bach, Calvet, and Sodini 2016), where the wealthiest families are invested in private equity, and families from the $50^{\text {th }}$ to $95^{\text {th }}$ percentiles are mainly invested in housing. In Sweden, as in the United States, leverage ratios also decline as assets increase.
} 
The main assets of families in the bottom 25 percent of the asset distribution are "other" assets, which include vehicles, savings bonds, cash-value life insurance, and other miscellaneous assets. Transaction accounts, such as checking and savings accounts, are the next most common assets, and only about 10 percent of the portfolio comprises housing and retirement assets. The debt-to-asset ratio of these families is more than 100 percent, and the mean asset value is about $\$ 9,000$ (Table 3). There are families of all ages in this group, but the average age of household heads is 43 , which is seven years younger than the average age of household heads in 2016. In the next section, we consider whether age and cohort may be influencing these results, but for now those factors are left untreated.

The asset portfolio of families near the median of the asset distribution - in the $25^{\text {th }}$ to $50^{\text {th }}$ percentiles or the $50^{\text {th }}$ to $60^{\text {th }}$ percentiles—is heavily skewed toward housing. ${ }^{10}$ Housing accounts for about 60 percent of the asset portfolio of these households, compared with 30 percent of the portfolio for the average household. The portfolio of households near the median also includes a smaller share of financial market and retirement assets; they make up less than 15 percent of assets, whereas they account for about 35 percent of assets in the average portfolio. The average value of assets for families in the $25^{\text {th }}$ to $50^{\text {th }}$ percentiles is about $\$ 97,000$, and it is about $\$ 228$, 000 for families in the $50^{\text {th }}$ to $60^{\text {th }}$ percentiles (Table 3 ).

The portfolio composition of families in the $80^{\text {th }}$ to $90^{\text {th }}$ percentiles and $90^{\text {th }}$ to $99^{\text {th }}$ percentiles is similar to that of the average portfolio, underscoring how different the aggregate portfolio is from most families' portfolios. However, the top 1 percent's portfolio is dominated by business and financial market assets, highlighting the concentration of these assets at the top the distribution.

The composition of portfolios across the distribution in 1989 is fairly similar to what it is at the end of the sample, in 2016 (bottom panel of Figure 3). In both years, the most common asset for families in the bottom 25 percent of the distribution, for example, is "other" assets; in both years, the most common asset for most families is housing; and the most common assets for the top 1 percent are privately held businesses and financial market assets. However, we can see the rise of retirement account assets across the distribution (the light-gray-striped bars) and the rise

\footnotetext{
${ }^{10}$ The asymmetry of the groups we use to show portfolios across the distribution is largely a function of the concentration of assets in the right tail of the distribution.
} 
of financial market assets (the medium-gray-striped bars). The leverage ratio is typically higher in 2016 for all percentile groups below the $80^{\text {th }}$ percentile, underscoring the increase in debt observed for most families.

Figure 3 also shows the ratio of total debts to total assets - a measure of leverage - for each percentile group in black (with scale on the right-hand side). Two things stand out: Leverage generally increased between 1989 and 2016, and - within a given year-leverage decreases as assets increase.

First, despite the decline in aggregate debt after 2010, leverage ratios are higher for each group below the $80^{\text {th }}$ percentile in 2016 than in 1989. For families in the bottom 25 percent of the asset distribution, the leverage ratio is almost 1.4, meaning that they have aggregate debts that are almost 40 percent greater than aggregate assets; in 1989 this figure stood at 0.9. Much of the increase is due to education debt, which is almost 70 percent of this group's debt in 2016 (Appendix Figure 1). ${ }^{11}$

Second, leverage ratios are lowest at the top of the asset distribution and rise steadily moving down the asset distribution. Increases in the leverage ratio are incremental across the top three-quarters of the asset distribution, and they rise sharply for the bottom 25 percent. In 2016, for example, the leverage ratio for the $90^{\text {th }}$ to $99^{\text {th }}$ percentiles is less than 0.10 , but it is about 0.45 for the $50^{\text {th }}$ to $60^{\text {th }}$ percentiles. Families in the middle percentiles hold mostly housing assets, which is typically a highly leveraged asset.

Because the main asset of families in the middle percentiles is housing, and housing is typically financed by debt, we re-ran Figure 3 and included home equity - the asset value of the home minus the outstanding debt on the home - in place of the asset value of the home (not shown). When we use this measure, housing accounts for a smaller share of the asset bundle for families in each percentile, and for the percentiles where average leverage ratios are highest, the share reduction is typically greater. But, the qualitative takeaways from Figure 3 remain unchanged, and housing continues to be the dominant asset for most families, especially those in the $25^{\text {th }}$ to $80^{\text {th }}$ percentiles.

\footnotetext{
${ }^{11}$ Mortgage debt makes up the largest share of debt for all groups except the bottom 25 percent (Appendix Figure 1). The share of debt in mortgages to finance a primary or secondary residence is about 75 percent, on average, and is from 75 to 90 percent for most asset percentile groups.
} 


\section{Across Time}

Looking at just the bookend years can obscure the changes in the distribution across the whole 1989-2016 sample. Figures 4 and 5 show these changes across survey years by plotting the share of assets in two key assets-housing and financial markets - for families near the median (the $25^{\text {th }}$ to $50^{\text {th }}$ percentiles or the $50^{\text {th }}$ to $60^{\text {th }}$ percentiles), near the $75^{\text {th }}$ percentile (the $70^{\text {th }}$ to $80^{\text {th }}$ percentiles), the $90^{\text {th }}$ to $99^{\text {th }}$ percentiles, and the average.

The most noticeable feature of Figure 4 is that for families in the $80^{\text {th }}$ percentile and below (represented by the $25^{\text {th }}$ to $50^{\text {th }}$, the $50^{\text {th }}$ to $60^{\text {th }}$, and $70^{\text {th }}$ to $80^{\text {th }}$ percentiles), housing has always been the key asset, usually ranging from 55 percent to 65 percent of assets. However, each group shows the same cyclical trend as the average: Housing became less important in the late 1990s, more important in the mid-2000s, and then less important again by 2016 .

The share of assets in financial and retirement assets (Figure 5) slowly trended up for families in the $25^{\text {th }}$ to $50^{\text {th }}$ and $50^{\text {th }}$ to $60^{\text {th }}$ percentiles, but it remained relatively low-from 10 percent to 15 percent of assets - between 1998 and 2016. Families in the $70^{\text {th }}$ to $80^{\text {th }}$ percentiles had a higher share of financial and retirement assets - about 20 percent - after 1998, though the share ticked up to about 25 percent by the end of the sample.

The share of assets in housing and the share in financial and retirement assets for the families in the $90^{\text {th }}$ to $99^{\text {th }}$ percentiles almost perfectly tracked the average share of assets in housing over time, both in level and in trend.

An important factor in the accumulation of wealth (distinct from net savings and inheritances) over time is the accrual of capital gains. The longer assets are held, and the more the asset prices increase over the period of ownership, the larger the gains in wealth. For several major asset classes (real estate, directly held businesses, and equities), the SCF includes information that allows us to measure unrealized capital gains. Unrealized gains account for an important share of total assets, particularly for wealthier families. During the 1989-2007 period, unrealized gains accounted for 25 percent to 35 percent of total assets for the $90^{\text {th }}$ to $99^{\text {th }}$ percentiles (Figure 6). Over this same period, unrealized gains were about one-third of total assets for households around the middle of the asset distribution. 
During the 2008-2009 financial crisis, the collapse of the housing and stock markets resulted in dramatic losses in wealth and a sharp decline in the unrealized gains share of assets. On average, the unrealized gains share fell more than 10 percentage points, dropping from 36 percent of all assets in 2007 to 24 percent in 2010. With the recovery of the stock market in 2010 , the unrealized gains share started to recover at the top of the distribution. For the $70^{\text {th }}$ to $80^{\text {th }}$ percentiles and below, however, the unrealized gains share kept declining, as the housing market continued to languish from 2010 to 2013. Between 2013 and 2016, with the housing market recovering and the stock market booming, the unrealized gains share of assets rose across the distribution of assets.

\section{Asset Concentration}

During our 1989-2016 sample period, there was a well-documented increase in wealth concentration, evidenced by the rising share of wealth held by the "top 1 percent" of families in the SCF (Bricker et al. 2016), in capitalized income tax data (Saez and Zucman 2016; Bricker, Henriques, and Hansen 2018), and in a combination of the SCF and other wealth surveys (Fisher et al. 2018). The focus of this paper is household assets, while the focus of other papers is wealth - the difference between household assets and debts.

As shown in Figure 7, though, asset concentration increased along with wealth concentration during our sample period. From 1989 through 1992, the top 1 percent of families — ranked by asset holdings — owned about 27 percent of all assets. This share increased to about 30 percent during the 1995 survey year and remained at that level through the 2010 survey year. After that, though, the share rose, notably, to 32 percent and then to 35 percent in the 2013 and 2016 surveys, respectively.

The asset concentration plateau from about 1995 through 2010 is generally consistent with wealth concentration estimates from the SCF (Bricker et al. 2016; Kuhn, Schularick, and Steins 2018) and from estate tax data (Kopczuk and Saez 2004; Saez and Zucman 2016). The SCF also shows a notable increase in wealth concentration between 2010 and 2016; there are no recent estate tax data estimates, though. These wealth concentration estimates stand in contrast to those first published from capitalized income tax data (Saez and Zucman 2016), in which wealth concentration estimates rise fairly steadily from 1989 through 2013, though tweaking the 
capitalization model assumptions generally reproduces the SCF and estate-tax wealth concentration trend (Bricker, Henriques, and Hansen 2018).

In each survey year, the share of assets held by the top 1 percent — ranked by assets — is smaller than the corresponding share of wealth held by the wealthiest top 1 percent, usually by about 3 to 5 percentage points (not shown; see Bricker et al. 2016). Leverage tends to increase as assets decrease (Figure 3), which reflects the leading role of housing in the asset bundle held by families outside of the top asset groups and which serves to equilibrate asset concentration relative to wealth concentration.

The asset share for the top 10 percent is similar to that of the top 1 percent-described above-which started rising slowly in the 1990s and then somewhat more rapidly in the 2010s, such that the top 10 percent held 70 percent of total assets by 2016 .

Concentration of assets and wealth has also occurred along other dimensions, including by income and by age. Higher-income families' share of total assets has risen, as has the share of assets held by older families. For example, in 2016, young families (with a head under age 45) held only 13 percent of total assets, down from about 30 percent in 1989 (Figure 8). The share of assets held by older families (head age 55 or older) rose from nearly 50 percent in 1989 to 70 percent in 2016.

Some of this shift in the distribution, certainly by age but also by income and asset group, is a result of the general trend toward an aging population that we have experienced over the last three decades. Assets are accumulated and wealth is built over time, and the life-cycle processes that influence household-level decisions could have important implications for the economywide levels, composition, and distribution of assets.

\section{Cohorts}

Life-cycle processes are important for understanding the evolution of wealth and its composition over time. The balance of debt and assets changes over the life cycle, as does the composition of assets. Young people take on debt, first as they build their human capital, and then as they take ownership of a primary residence. Accordingly, residential real estate dominates the balance sheets of young families. Progressing through life, families accumulate wealth that they will ultimately draw upon in retirement and potentially pass on to heirs in the 
form of bequests. ${ }^{12}$ Financial assets, including directly held equities and employment-related pension plans, become increasingly prominent over time. While these processes play out across individual households, they also influence the overall composition of wealth as society ages.

In this section, we seek to understand the ways in which the stylized life-cycle processes described above are different for different parts of the distribution. Since wealth is so highly concentrated, the life-cycle patterns observed at the mean of the data are driven primarily by wealth dynamics of households at the top of the distribution. We are interested in seeing if households at the bottom or the middle of the distribution exhibit the same broad life-cycle patterns exhibited in the aggregate data. In addition, we would like to know how the 2008-2009 financial crisis affected life-cycle patterns across the wealth distribution and for different birth cohorts.

The composition of wealth also differs dramatically across the wealth and income distributions. Businesses and directly held financial assets account for a substantial portion of assets for families at the top of the distribution, but for only a minor share for those at the middle, and they are almost completely absent from the assets of families at the bottom. Housing dominates the asset portfolios of households at the middle of the distribution, and illiquid assets - primarily vehicles - account for the lion's share of assets for households at the bottom. Since the portfolios of low-, middle-, and high-wealth families substantially differ from each other, the long-term trends toward rising concentration in the distribution of wealth might also be influencing the overall composition of wealth. Part of the cohort analysis will explore how these different components of wealth evolve over the life cycle for households at different levels of the normal income distribution, and it will examine whether recent cohorts are following patterns similar to those that previous cohorts followed.

Household saving decisions are, of course, not solely motivated by life-cycle considerations. The need to smooth consumption against adverse shocks - through precautionary savings-is

\footnotetext{
${ }^{12}$ Households tend not to exhaust their wealth, with substantial numbers leaving inheritances for future generations. Past research concludes that the bequest motive is powerful and accounts for one-third to as much as one-half of all savings (Davies and Shorrocks 2000; Kopzcuk and Lupton 2007). Whether it is best to view bequests as a distinct motive for saving that is separate from the life-cycle model (Kotlikoff and Summers 1981) and one that can be incorporated into the standard model through extension is beyond the scope of this chapter. As a practical matter, we follow Dynan, Skinner, and Zeldes (2002) and think of the motivation for saving at older ages (precautionary vs. bequest) as potentially impossible to disentangle. The focus of this paper is less on the precise motive for saving than it is on using the life-cycle process as a way to separate age effects from wealth trends.
} 
ubiquitous. Previous research using the SCF indicates that precautionary savings account for a relatively small but important part of total savings, particularly among younger households and business owners (Cagetti 2003; Hurst et al. 2010).

In this section, we explore the joint influence of these factors - age and location in the distribution - on trends in wealth and the composition of wealth using a cohort analysis of the SCF. We identify cohorts based on 10-year bins of birth year; the earliest of the six cohorts analyzed was born between 1924 and 1933 (ages 83 to 92 in 2016), and the most recent was born between 1974 and 1983 (ages 33 to 42 in 2016). For each of these cohorts, we also sort households by their location in the distribution of "normal" income for each year of the survey. The income groups we use are the bottom half of the distribution, the next- 45 percent (the $51^{\text {st }}$ through $95^{\text {th }}$ percentiles), and the top 5 percent.

The SCF asks households about not just wealth and income, but also about the income that households "usually" receive in a "normal year." Normal income is viewed as a proxy for permanent income, and previous research shows it to be a stable classifier that smooths transitory shocks and ranks households by the resources that are typically available to them (Ackerman and Sabelhaus 2012). Since the questions about normal income have been included in the SCF only since 1995, the analysis in this section is limited to the eight cross-sections from 1995 through 2016.

\section{Interpreting the Cohort Figures}

Below we examine trends in a select group of wealth indicators by birth-year and incomegroup cohorts. First, we explore trends in median cohort assets; then the share who own homes, equities, and business; the share holding a mortgage on their primary residence; and finally, the share of total assets accounted for by houses, equities, and businesses. Each of the nine figures in this section uses the same format, which, in order to aid interpretation, we will discuss in detail before introducing the first cohort figure.

The cohorts in the bottom half of the income distribution are depicted by dots, the next- 45 percent by solid lines, and the high-income cohorts by dashes. Each birth-year/income-group cohort is represented by a line segment that spans five, six, seven, or eight survey years. Most birth-year cohorts are represented in all eight of the SCF cross-sections from 1995 through 2016. The exceptions are the youngest cohort (born between 1974 and 1983), which is represented only 
from 2001 through 2016, and the oldest cohort (born between 1924 and 1933), which is represented only from 1995 through 2007.

All three income groups for each birth-year cohort are represented by the same color. For example, the lines for the most recent birth-year cohort (born between 1974 and 1983 and shown at the far left of the figure) are all the lightest shade of gray, with the lowest-income cohort in those birth years depicted by dots, the middle-income group by a solid line, and the highestincome group by dashes.

The numbers on the horizontal axis represent the lower bound of the 10-year age range for the birth cohorts when they appear in an SCF survey year. When multiple birth-year cohorts have adjacent lower-bound ages represented in the data, we show the mean of the lower-bound age. For example, the first time that we see the most recent cohort (born between 1974 and 1983) represented in the data is 2001 , when the youngest member of this cohort is 18 . The 1974-1983 cohort is the only one that we see at that age. Three years later, the youngest age from that birth cohort is 21 . The first time we observe the second-youngest birth cohort (born between 1964 and 1973 ) is in 1994, when the lower bound of the age range is 22 . We observe these two cohorts only around that age and represent the lower bound age on the horizontal axis with 22 (the rounded value of 21.5 ).

\section{Median Household Assets}

Figure 9 shows trends in the $\log (10)$ of median assets across the life cycle-adjusted for inflation using 2016 dollars - for 18 birth-year/income-group cohorts using SCF data from 1995 through 2016. For each normal-income group, we observe the anticipated growth in assets as the cohorts approach retirement age. Total assets peak for each income group when the midpoint of the age range is at or slightly above $60 .{ }^{13}$

Several differences between the high- and low-income cohorts stand out. First are the substantial differences in wealth across the entire life cycle. Peak median assets - reached between the ages of 54 and 63 for the cohort born between 1944 and 1953-are $\$ 6$ million for

\footnotetext{
${ }^{13}$ One issue that could affect the cohort analysis is the role of intergenerational transfers in asset accumulation, as younger households may be implicitly accumulating assets via their parents. Any transfers already received by households are included in their assets, but expected transfers are not included. Modeling the expected transfers is beyond the scope of this paper; see Feiveson and Sabelhaus (2018) for evidence on the role of intergenerational transfers from the SCF.
} 
the top income group, $\$ 698,000$ for the next-45 percent, and $\$ 170,000$ for the bottom half of the normal-income distribution. Similarly, wide differences across the normal-income groups are present at the younger ages and in retirement years.

Another notable difference is the relative performance of successive "generations" of cohorts and how they were affected by the 2008-2009 financial crisis. The period when the financial crisis occurs can be identified easily in Figure 9, as it is accompanied by a large decline in median assets for all birth-year cohorts and income groups. For the four middle cohorts (born between 1934 and 1973) that are represented by all eight surveys from 1995 through 2016, the financial crisis occurs in the fifth segment of each cohort line, which is book-ended by data from the 2007 and 2010 SCFs.

When we evaluate the cohorts at the same age levels, we see that more recent cohorts in the high-income group had higher median assets than the previous cohort in the period leading up to the financial crisis. For example, we observe the two successive birth-year cohorts born between 1944 and 1953 and 1954 and 1963 at the same ages five different times. In the survey years preceding the financial crisis, the median assets of the younger cohort were substantially higher. Following the crisis, median assets were approximately the same across successive cohorts.

Before the financial crisis, lower-income cohorts appear to have had median assets that were very similar to those of previous cohorts at the same age. After the crisis, more recent cohorts fell behind the previous generation. For example, when the members of the cohort born between 1954 and 1963 were over the ages of 44 to 53 , their median assets were $\$ 130,000$, which is slightly greater than the median of $\$ 114,000$ for the cohort born between 1944 and 1953 at those ages. Following the financial crisis, when the 1954-1963 cohort was over the ages of 50 to 59, their median assets fell to $\$ 70,400$, compared with median assets of $\$ 141,000$ for the previous cohort at the same ages.

In the next- 45 percent of the asset distribution, more recent cohorts consistently had higher median assets than previous cohorts in the years leading up to the financial crisis. Post-crisis, the more recent cohorts had median assets that were lower than those of previous cohorts. 


\section{Ownership of Risky Assets: Business, Equity, and Housing}

There are several different ways to think about the risk - the potential for losing valueassociated with different assets. Very few, if any, assets are truly free of risk. In an economy in which inflation has been low and stable for decades, bonds seem like a relatively safe asset, but that assumption of relatively low risk is dependent on inflation. The most dramatic form of risk, and the one that has dominated recent financial crises, is sharp, unexpected declines in asset prices. Using exposure to sharp declines in asset prices as the definition of risk, we identify three risky assets — businesses, equity, and housing — and explore how exposure to risk from these assets varies across income groups and over the life cycle.

\section{Business Ownership}

A substantial majority of high-income households have business assets, including both directly and passively run businesses (Figure 10). Business assets consist of privately held active or passive businesses, such as sole proprietorships, partnerships, limited-liability companies, subchapter $\mathrm{S}$ corporations, and $\mathrm{C}$ corporations. ${ }^{14}$ Business ownership is much less common among the next- 45 percent, and it is quite rare among those in the bottom half of the income distribution. We consider business assets as risky assets due to the exposure of businesses to competitive market forces, such as raw material input prices, labor costs, and output prices.

For all three income groups, we see business ownership peaking when household heads are in their forties and fifties, and then declining markedly when they are in their sixties. We see the pattern most clearly at the top incomes. When the heads are in their twenties and early thirties, roughly one-third of top 5 percent income families have business assets. This share climbs sharply with age, such that by the time the high-income-family heads are in their forties and fifties, nearly 70 percent own businesses. As the family heads enter retirement, business ownership among these households falls off considerably, dropping back to about one-third by the time the heads are in their seventies. All three income groups follow a similar arc over the life cycle, with rates of business ownership in retirement returning to levels that earlier cohorts from the same income group had exhibited in their twenties.

\footnotetext{
${ }^{14}$ Note that business assets are measured as the equity value of the business.
} 
For families in the top half of the income distribution, we see that business ownership is less common among the 1944-1953 and 1934-1943 cohorts than among those that followed. This is particularly evident in the top 5 percent of the distribution, where business ownership in the 1944-1953 cohort is greater than that in the 1934-1943 cohort at every comparable age. Likewise, business ownership among the 1934-1943 cohort consistently outstrips that of the cohort born between 1924 and 1933. For the most recent cohorts, and in the bottom half of the income distribution, there is no general movement toward or away from business ownership.

\section{Equity Ownership}

For all income groups, ownership of equity is considerably more common than ownership of businesses (Figure 11). Equity includes both direct holdings of stocks and stocks in pooled investment funds and indirect holdings in retirement accounts (401(k), IRA, and other defined contribution accounts) and other managed assets (trusts, annuities, and managed investment accounts). We consider equities risky assets due to their exposure to price volatility in equity markets. By the time the household head reaches age 30, equity ownership is nearly universal among top-income households. Equity holding falls off only slightly as the heads of high-income families enter retirement age.

Large majorities of families in the next-45 percent of the income distribution also hold equities in one form or another. For most cohorts and ages, the rate of equity ownership among the middle-income group lags only that of the top-income group by 10 to 15 percentage points. A non-trivial share of families in the bottom half of the income distribution also own equities; the share with equities peaks at just over 40 percent when household heads are in their forties. The decline in equity ownership is more pronounced for the low- and middle-income groups than it is for the top-income group. As the low- and middle-income household heads enter retirement age, the share owning equities falls off nearly 20 percentage points.

One pattern shared broadly across the income groups is the rise in equity ownership across successive generations of cohorts. Expanded equity holding is particularly evident after age 30, is limited to the cohorts born before 1964, and occurs primarily between 1989 and 2001. Within the middle-income group, these changes are especially dramatic. Equity ownership for the cohort born between 1934 and 1943 is 30 points higher than it is for the previous birth-year cohort when both reach ages 61 to 70 . 


\section{Home Ownership}

The final risky asset, housing, is one that some might not categorize as risky. However, we feel that given housing is the largest asset held by most households and the volatility in house prices over the past few decades, housing should be considered a risky asset.

When the household head is older than 40 , home ownership is nearly universal for households in the top half of the income distribution (Figure 12) ${ }^{15}$ Ownership climbs sharply when household heads are in their twenties and thirties, peaks at over 90 percent after they reach 40 , and remains high when they are in retirement.

Home ownership is much less common for lower-income households, but even among households in the bottom half of the income distribution, home ownership climbs steadily with the age of the household head. The rate of ownership does not peak until the household heads are in their late sixties, when nearly 80 percent own homes.

After the financial crisis, the rate of ownership outside of the top-income group fell, relative to that of previous birth-year cohorts. For households in the next-45 percent of the income distribution, for example, the home ownership rate of the most recent cohort (born between 1974 and 1983) was 71 percent when they were ages 34 through 43, compared with an ownership rate of 85 percent for the previous birth-year cohort at those ages. The decline in ownership is even more widespread in the bottom half of the income distribution. Following the crisis, each of the three most recent cohorts of lower-income families (born after 1953) had ownership rates that were 10 percentage points lower than those of the preceding birth-year cohort.

\section{Mortgage Holding}

The share of households with a mortgage for a primary residence rises sharply when household heads are in their twenties and thirties, paralleling the rise in home ownership (Figure 13). Mortgage holding, though, begins to decline after age 40 , while home ownership remains steady or, in the case of lower-income households, continues to rise. As the household heads enter their forties, roughly 8 in 10 households in the top half of the income distribution hold mortgages, but this share falls sharply as household heads approach and enter retirement. Fewer

\footnotetext{
${ }^{15}$ Home ownership refers to ownership of the primary residence and does not include ownership of any other residential real estate.
} 
than 15 percent of households in the oldest cohort, regardless of income level, held mortgages when the heads were ages 73 through 82 .

Trends in mortgage holding across successive birth-year cohorts share some features with home ownership trends, but they are also distinct in important ways. In addition to the decline in home ownership among more recent cohorts after the financial crisis, we see lower rates of mortgage holding for the same groups over the same period. For the middle-income group, 66 percent of the 1974-1983 cohort held a mortgage when the household heads were over the ages of 34 through 43, compared with 82 percent of the previous birth-year cohort at those ages. Among older cohorts (those born before 1954), however, the rates of mortgage holding are substantially higher compared with those of previous birth-year cohorts. This rise in mortgage holding is present for all income groups. For example, when the household heads in the 19341943 cohort were ages 70 through 79, households were 7 percent to 9 percent more likely, depending on their income level, than the previous birth-year cohort to be holding a mortgage.

\section{The Risky Asset Share}

This section explores the share of total assets held in these three risky asset types, and how those shares evolve over the life cycle for different income groups.

\section{Business Share}

Businesses represent a substantial share of assets only for high-income cohorts. Unlike the likelihood of owning a business, however, there is little curvature in the business share of assets over the life cycle (Figure 14). For the high-income group, businesses account for approximately one-third of total assets when household heads are in their thirties, forties, and fifties, and as these households transition into retirement, the business share declines modestly. One implication is that the businesses high-income households shed in retirement are relatively lowvalue companies, and possibly, they retain the more valuable businesses for bequest purposes.

For low- and middle-income households, businesses account for roughly 10 percent of total assets over most of the life cycle. As the heads of these households enter retirement, the business share declines and approaches zero.

When comparing business shares across successive cohorts by income group, we find few systematic differences when we move from one birth-year cohort to the next. The two 
differences that do stand out are within the high-income group, at the tails of the age distribution. The business asset share was higher among the more recent of the two represented cohorts when the household heads were at the youngest and oldest age levels. When the heads of the most recent cohort (born between 1974 and 1983) were in their early twenties to mid-thirties, the households' business share was from 10 to 20 percentage points higher than that of the previous birth-year cohort at those ages. At the other end of the life cycle, the 1934-43 cohort has a business share that is from 2 to 6 percentage points higher than that of the previous birth-year cohort at four out of the five points where we view them at the same ages.

\section{Equity Share}

In both levels and patterns over the life cycle, the equity share is quite similar across income groups (Figure 15). For the three birth cohorts whose household heads we view at ages 54 through 63, the equity share of assets averages 27 percent among top-income households, 22 percent for the next-45 percent of households, and 11 percent in the bottom half of the income distribution. The equity share also rises slowly and steadily across the life cycle. As households hit retirement age, the equity share appears to flatten out in the top half of the income distribution and modestly decline in the bottom half.

\section{Housing Share}

The housing share of total assets rises sharply for all income groups at the very youngest ages that we observe households (Figure 16). When household heads are in their twenties, the housing share is also similar across income groups. For the 1964-1973 cohort, the housing share at ages 22 through 31 was 43 percent for top-income households, 46 percent for the next-45, and 35 percent for the bottom half of the distribution. When household heads are in their thirties and beyond, the housing share behaves quite differently by income.

Among high-income households, the housing share falls steadily with the age of the household heads until it accounts for slightly more than 10 percent of total assets when heads are in their late forties through their early eighties. For the middle-income group, the housing share remains mostly flat — at about 50 percent — when household heads are in their thirties, and it starts to steadily fall as they enter their forties. The housing share appears to bottom out at roughly 30 percent of total assets when the middle-income group heads hits their mid-fifties. For the oldest cohort (1924-1933), the housing share started to rise as household heads entered their 
seventies, presumably as these retirees continued to live in their homes and began to draw down other assets.

Across the entire life cycle, housing remains the dominant asset for households in the bottom half of the income distribution. Housing accounts for just over half of all assets of the low-income group when the household heads are in their mid-twenties through thirties. The housing share declines slightly when the household heads are in their forties, but it never falls below 40 percent of total assets. As the heads of low-income households approach retirement age, though, the housing share starts to rise markedly. It climbed to well over 60 percent for the older cohort when they were in their seventies. It looks as is if the drawdown of non-housing assets happens earlier and more rapidly in the bottom half of the income distribution than in the next-45 percent of the distribution.

\section{Combined Risk Asset Share}

Despite the clear differences between low-, middle-, and high-income groups regarding the business share and housing share of total assets, the combined risky asset share is very similar over the life cycle for the different income groups. For each group, the share rises when the household heads are in their twenties and peaks at 70 percent to 80 percent of all assets when the heads are in their thirties (Figure 17). When the household heads are in their forties through sixties, the combined risky asset share slowly and steadily declines, hitting 60 percent to 70 percent at the transition into retirement. Each income group exhibits a small uptick in the combined risky asset share when the household heads are in their seventies.

\section{Financial Vulnerability, Shocks, and the Health of the Household Balance Sheet}

In the previous sections, we saw that asset composition varies considerably across the asset distribution (section V) and across the age and income distributions (section VI). In this section, we discuss how these portfolio differences influence the level of financial risk to which families are exposed, and how this exposure has evolved over time. First, we discuss how housing and equity-price shocks would affect wealth across the distribution. Second, we discuss exposure to risk that takes housing leverage, consumer debt, and income into account.

\section{Risk from Asset-price Shocks}

The composition of asset portfolios for middle-class families - the $51^{\text {st }}$ through $95^{\text {th }}$ percentile by assets (Figure 3) and by income (Figure 16) — is heavily skewed toward housing. 
Housing is a highly leveraged asset for these families: Their average debt levels are about 40 percent of their total assets (Figure 3), and mortgages account for about 75 percent of their total debts (Appendix Figure 1). On the other hand, families with high levels of assets and income often hold extensive public and private equity positions (Figures 3, 14, and 15).

While equity is the traditional barometer of portfolio riskiness, house-price declines often affect a family's wealth position to a greater degree due to leverage. Here, we calculate the share of total household wealth lost from two hypothetical asset-price shocks - a 10 percent decline in house prices and a 10 percent decline in equity prices - and the share of households that experience large losses from these shocks.

Families outside of the top 5 percent income group are particularly susceptible to a housing shock. In 2016, these families would have lost, on average, from 4 percent to 6 percent of their net worth from a 10 percent decline in house prices. Further, 9 percent of the bottom 50 percent of the income distribution and 24 percent of the next- 45 percent would have lost more than 10 percent of their net worth (Table 4).

The top 5 percent would have lost about 1 percent of their total net worth, and only about 4 percent of these families would have lost more than 10 percent of wealth from this hypothetical shock. These families, though, would have lost about 7 percent of their wealth due to the hypothetical equity-price decline, while lower-income families would have lost 3 percent to 4 percent. ${ }^{16}$

We apply these shocks to earlier waves of SCF to see what the impact of leveraged housing would have been on middle-income ( $51^{\text {st }}$ to $95^{\text {th }}$ percentile) family net worth in the early to mid2000s. In 2007, for example, 33 percent of these families would have lost 10 percent of their wealth from a 10 percent house-price decline. ${ }^{17}$ In general, though, the fraction of these families who would have lost more than 10 percent of wealth was lower in 2016 than in 2010 or 2013, indicating that these families were a bit less susceptible to a house-price shock in the later year (as shown in Haughwout, Guttman-Kenney and Fuster 2018; and Bhutta et al. 2018).

\footnotetext{
${ }^{16}$ Included here are equities - directly or indirectly held — and businesses.

17 The loss in 2010 is larger than in 2007, because the families in the 2010 SCF had already experienced a large house-price decline - averaging 25 percent over the previous three years - while the 2007 SCF households had just begun to experience a decline in house prices.
} 


\section{Financial Vulnerability: Income and Asset-Price Shocks ${ }^{18}$}

These hypothetical asset-price shocks are suggestive, but they do not identify all of the households whose portfolios are vulnerable to adverse shocks. For one thing, asset-price shocks usually are accompanied by a labor market shock - as a cause or as an effect. Given the large role of housing and housing debt in shocks in Table 3, we further investigate the health of the household balance sheet by looking at how vulnerable families are to simultaneous house-price and income shocks.

Figure 18 shows the joint distribution of household loan-to-value (LTV) ratios and debtservice ratios, in the form of debt-payment-to-income (PIR) ratios, in the 2016 SCF. The columns describe levels of LTVs; the rows describe levels of PIRs; and the number in each cell indicates the fraction of families in that cell. We illustrate it this way because families are more susceptible to financial distress - and more likely to default — when they experience both an income and house-price shock. ${ }^{19}$

All else being equal, declines in income move families down the heat map, resulting in higher PIRs. Declines in house prices move families across the heat map (to the right), resulting in higher LTVs. Families in the darkest gray cells have a combination of very elevated LTVs and very elevated PIRs, and they are thus the most vulnerable to economic shocks. Families in the lighter gray cells have elevated PIRs or LTVs and may also be vulnerable. Families in the white cell include renters as well as homeowners with very low LTVs due in many cases to the absence of a mortgage.

One lesson from the heat map is that very few families in 2016-about 2 percent-were coded in dark gray. Another 5 percent of families were shaded in medium gray, demonstrating either vulnerability on one- but not both - dimensions or borderline vulnerability along both dimensions. A large majority of families occupied the white area, where debt payment and loan balances are considered manageable.

\section{Trends in Vulnerability across Time}

Using the same color scheme from the heat map in Figure 18, we can track fluctuations in this multidimensional vulnerability measure over time. Figure 19 displays the cell totals in a

\footnotetext{
${ }^{18}$ This discussion was inspired by conversations with our colleagues Neil Bhutta, Lisa Dettling, Joanne Hsu, Alice Henriques, and Lindsay Jacobs.

${ }^{19}$ See, for example, evidence for the double trigger theory of mortgage default in Bricker and Bucks (2016) or Foote, Gerardi, and Willen (2008).
} 
stacked bar (omitting the white group) to facilitate a comparison over time. We see that in 2016 fewer families met any degree of vulnerability/susceptibility to an economic shock than in previous survey years back to 2001. This decline was driven mainly by fewer families occupying the dark gray and medium gray areas - where LTVs and PIRs are the most elevated. The fraction of families in the dark gray area fell by a third after its peak in 2010, and the area of dark and medium gray cells combined halved after 2010. In the aftermath of the financial crisis, just over 13 percent of all households were identified as financially vulnerable.

Both the levels and the trends in financial vulnerability vary by income group. This makes sense, as homeownership, income, and debt each vary differently across these groups.

For the bottom half of the income distribution, financial vulnerability remained flat over most of the last two decades, fluctuating around 20 percent (Figure 20). It fell to a modern lowpoint in 2016, when only 7.5 percent of families in the bottom half of the income distribution were shaded as either dark gray or medium gray. At the peak in 2010, nearly 11 percent of families had extreme (dark gray) or moderate (medium gray) financial vulnerability.

The highest levels and greatest degree of variation over time in financial vulnerability is seen among the families in the next-45 percent of the income distribution (Figure 21). These families have high rates of home ownership and carry substantial debt, tied particularly to their homes, so joint income and house-price shocks hit them hardest. By 2010 - after a large houseprice shock - nearly 35 percent were vulnerable in some way, with 16.5 percent in dark gray or medium gray areas. In 2016, after seven years of economic expansion, financial vulnerability among the next-45 had receded to 2001 levels, particularly for the dark gray and medium gray areas.

Financial vulnerability is unsurprisingly lowest among high-income families (Figure 22). Between 2007 and 2010, the share of high-income families coded as either dark gray or medium gray jumped from 3.5 percent to more than 7 percent. By comparison, the combined post-crisis measure of vulnerability among high-income families remained below that of middle- and lowerincome families in the very best of economic times. By 2016, financial vulnerability at the top of the income distribution had receded sharply, with just 2.5 percent of those families coded as dark gray or medium gray. 


\section{Conclusion}

Understanding developments in household portfolios is arguably more important than ever. To identify the causes and consequences of a long-term rise of inequality in the distribution of wealth, and to monitor the degree of financial vulnerability that households face, it is crucial to understand the allocation of assets across asset types, age groups, and the distribution of income.

The data from the Survey of Consumer Finances (SCF) that we reviewed establishes clear patterns that allows us to draw several conclusions. First, the household asset portfolio inferred from aggregate data - which is spread across housing and financial assets - does not look like the portfolio of most households, which is composed mostly of housing assets. Second, the time series dynamics of the aggregate portfolio - which has swung toward and from financial assetsdo not appear in the time series of most families, whose portfolios have always been composed mostly of housing. This is also the case when taking a longer view of household assets (Kuhn, Schularick, and Steins 2018).

Third, we also see a slow and steady increase in the concentration of assets, which picked up in the 2010-2016 period. Since the processes that create wealth for a household unfold over time, the relationship between assets and age can be complicated. We also explore the trends in asset levels and portfolio composition over the life cycle using a birth-year/income-group cohort analysis of the SCF.

Fourth, viewing the data through birth-year cohorts by income, we observe the typical lifecycle asset accumulation processes among low-, middle-, and high-income families. Though the levels are of different magnitudes, assets generally increase throughout the typical working life in each income group, and they peak just before the typical retirement age before partially decumulating.

However, recent cohorts have fallen behind in homeownership and asset accumulations. In general, though, recent cohorts are also more highly educated than previous cohorts (Figures 23 and 24), so these gaps may close if the past relationship between education and wealth persists. Another paper (Kurz, Li, and Vine 2018) shows that the relationship between consumption, income, and wealth for younger cohorts (Millennials) is similar to what it is for older cohorts (Generation $\mathrm{X}$ and baby boomers).

Finally, we focus on quantifying financial vulnerabilities in family balance sheets. We first show that families with a combination of two potential vulnerabilities - high debt payments and 
high loan-to-value ratio on their primary residence - peaked in the late 2000s and in 2016 were at the lowest level since the early 1990s. We also show that nearly all of the time series variation is due to middle-income families, who also hold most of their assets in housing and are often the most highly leveraged income group in the housing market. 


\section{References:}

Ackerman, Samuel, and John Edward Sabelhaus. 2012. "The Effect of Self-Reported Transitory Income Shocks on Household Spending." Finance and Economics Discussion Series 201264. Board of Governors of the Federal Reserve System.

Bach, Laurent, Laurent Calvet, and Paolo Sodini. 2016. "Rich Pickings? Risk, Return, and Skill in the Portfolios of the Wealthy." CEPR Discussion Paper 11734.

Benmelech, Effi, Ralf Miesenzahl, and Rodney Ramcharan. 2017. "The Real Effects of Liquidity during the Financial Crisis: Evidence from Automobiles." Quarterly Journal of Economics 132(1): 317-365.

Bertaut, Carol, and Martha Starr-McCluer. 2002. "Household Portfolios in the United States." Finance and Economics Discussion Series 2002-26. Board of Governors of the Federal Reserve System.

Bhutta, Neil, Jesse Bricker, Lisa Dettling, Jimmy Kelliher, and Steve Laufer. 2018. "Stress Testing Household Debt."

Bricker, Jesse, Alice Henriques, and Peter Hansen. 2018. "How Much Has Wealth Concentration Grown in the United States? A Re-Examination of Data from 2001-2013." Finance and Economics Discussion Series 2018-24. Board of Governors of the Federal Reserve System.

Bricker, Jesse, Lisa J. Dettling, Alice Henriques, Joanne W. Hsu, Lindsay Jacobs, Kevin B. Moore, Sarah Pack, John Sabelhaus, Jeffrey Thompson, and Richard A. Windle. 2017. "Changes in U.S. Family Finances from 2013 to 2016: Evidence from the Survey of Consumer Finances." Federal Reserve Bulletin 103(3): 1-41.

Bricker, Jesse, Alice Henriques, and Kevin Moore. 2017. "Updates to the Sampling of Wealthy Families in the Survey of Consumer Finances." Finance and Economics Discussion Series 2017-114. Board of Governors of the Federal Reserve System.

Bricker, Jesse, Alice Henriques, Jacob Krimmel, and John Sabelhaus. 2016. "Measuring Income and Wealth at the Top Using Administrative and Survey Data." Brookings Papers on Economic Activity Spring.

Bricker, Jesse, and Brian Bucks. 2016. "Negative Home Equity, Economic Insecurity, and Household Mobility over the Great Recession." Journal of Urban Economics 91(January): $1-12$.

Cagetti, Marco. 2003. "Wealth Accumulation over the Life Cycle and Precautionary Savings." Journal of Business \& Economic Statistics 21(3): 339-353.

Cagetti, Marco, and Mariacristina De Nardi. 2006. "Entrepreneurship, Frictions, and Wealth." Journal of Political Economy 114(5): 835-870.

Campbell, John. 2006. "Household Finance." Journal of Finance 61(4): 1553-1604.

Carroll, Christopher, Jiri Slacalek, Kiichi Tokuoka, and Matthew N. White. 2017. "The Distribution of Wealth and the Marginal Propensity to Consume." Quantitative Economics 8(3): $977-1020$. 
Davies, James B, and Anthony F. Shorrocks. 2000. "The Distribution of Wealth," in Handbook of Income Distribution, edited by Anthony B. Atkinson and Francois Bourguignon. Amsterdam, the Netherlands: Elsevier/North Holland.

Dettling, Lisa J., Sebastian J. Devlin-Foltz, Jacob Krimmel, Sarah J. Pack, and Jeffrey P. Thompson. 2015. "Comparing Micro and Macro Sources for Household Accounts in the United States: Evidence from the Survey of Consumer Finances." Finance and Economics Discussion Series 2015-086. Board of Governors of the Federal Reserve System.

Dettling, Lisa J., and Joanne W. Hsu. 2014. "The State of Young Adults' Balance Sheets: Evidence from the Survey of Consumer Finances." Federal Reserve Bank of St. Louis Review 96(4): 305-330.

Devlin-Foltz, Sebastian, Alice M. Henriques, and John E. Sabelhaus. 2016. "Has Tax-Preferred Retirement Saving Offset Rising Wealth Concentration?" FEDS Notes. Washington: Board of Governors of the Federal Reserve System, July 29, 2016, http://dx.doi.org/10.17016/2380-7172.1811.

Dynan, Karen, Jonathan Skinner, and Stephen Zeldes. 2002. "The Importance of Bequests and Life-Cycle Saving in Capital Accumulation: A New Answer." The American Economic Review 92(2): 274-278.

Feiveson, Laura, and John Sabelhaus. 2018. "How Does Intergenerational Wealth Transmission Affect Wealth Concentration?" FEDS Notes. Washington: Board of Governors of the Federal Reserve System, June 1, 2018, https://doi.org/10.17016/2380-7172.2209.

Fisher, Jonathan, David Johnson, Timothy Smeeding, and Jeffrey Thompson. 2018. "Inequality in 3-D: Income, Consumption, and Wealth." Finance and Economics Discussion Series 2018-001. Board of Governors of the Federal Reserve System.

Foote, Christopher, Kristopher Gerardi, and Paul Willen. 2008. "Negative Equity and Foreclosure: Theory and Evidence.” Journal of Urban Economics 64(2): 234-245.

Foote, Christopher, Lara Lowenstein, and Paul Willen. 2016. "Cross-Sectional Patterns of Mortgage Debt during the Housing Boom: Evidence and Implications." Federal Reserve Bank of Boston Research Department Working Papers No. 16-12.

Gallin, Joshua H., Raven Molloy, Eric Nielsen, Paul Smith, and Kamila Sommer. 2018. "Measuring Aggregate Housing Wealth: New Insights from an Automated Valuation Model." Finance and Economics Discussion Series 2018-064. Washington: Board of Governors of the Federal Reserve System, https://doi.org/10.17016/FEDS.2018.064.

Haliassos, Michael, and Carol C. Bertaut. 1995. "Why Do So Few Hold Stocks?" The Economic Journal 105(432): 1110-1129.

Haughwout, Andrew, Benedict Guttman-Kenney, and Andreas Fuster. 2018. "Tracking and Stress-Testing U.S. Household Leverage.” Economic Policy Review 24(1): 35-63.

Henriques, Alice, Lindsay Jacobs, Elizabeth Llanes, Kevin Moore, and Jeffrey Thompson. Forthcoming. "Wealth Distribution and Retirement Preparation among Early Savers." Finance and Economics Discussion Series. Board of Governors of the Federal Reserve System. 
Henriques, Alice M., and Joanne W. Hsu. 2014. "Analysis of Wealth Using Micro and Macro Data: A Comparison of the Survey of Consumer Finances and Flow of Funds Accounts," in Measuring Economic Sustainability and Progress, Studies in Income and Wealth, Vol. 72, edited by Dale W. Jorgenson, J. Steven Landefeld, and Paul Schreyer. Cambridge, MA: National Bureau of Economic Research.

Hurst, Erik, Anna Maria Lusardi, Arthur Kennickell, and Francisco Torralba. 2010. "The Importance of Business Owners in Assessing the Size of Precautionary Savings. ” Review of Economics and Statistics 92(1): 61-69.

Kennickell, Arthur B. 2008. "The Role of Over-sampling of the Wealthy in the Survey of Consumer Finances." The IFC's Contribution to the $56^{\text {th }}$ ISI Session. Bank of International Settlements IFC Bulletin No. 28.

Kennickell, Arthur B., and R. Louise Woodburn. 1999. "Consistent Weight Design for the 1989, 1992, and 1995 SCFs, and the Distribution of Wealth." Review of Income and Wealth 45(2): 193-215.

Kennickell, Arthur B. 1999. "Revisions to the SCF Weighting Methodology: Accounting for Race/Ethnicity and Homeownership."

Kotlikoff, Laurence, and Lawrence Summers. 1981. "The Role of Intergenerational Transfers in Aggregate Capital Accumulation." Journal of Political Economy 89(4): 706-732.

Kopczuk, Wojciech, and Emmanuel Saez. 2004. "Top Wealth Shares in the United States, 19162000: Evidence from Estate Tax Returns." National Tax Journal 62(2): 445-487.

Kopczuk, Wojciech, and Joseph Lupton. 2007. "To Leave or Not To Leave: The Distribution of Bequest Motive.” The Review of Economic Studies 74(1): 207-235.

Kuhn, Moritz, Moritz Schularick, and Ulrike Steins. 2018. "Income and Wealth Inequality in America, 1949-2016."

Kurz, Christopher, Geng Li, and Dan Vine. 2019. “Are Millennials Different?" In Handbook of US Consumer Economics $1^{\text {st }}$ edition, edited by Andrew Haughwout and Benjamin Mandel. Cambridge, MA: Academic Press.

Mian, Atif, Kamalesh Rao, and Amir Sufi. 2013. "Household Balance Sheets, Consumption, and the Economic Slump." The Quarterly Journal of Economics 128(4): 1687-1726.

Moskowitz, Tobias J., and Annette Vissing-Jørgensen. 2002. "The Returns to Entrepreneurial Investment: A Private Equity Premium Puzzle?" American Economic Review 92(4): 745778.

O'Muircheartaigh, Colm, Stephanie Eckman, and Charlene Weiss. 2002. "Traditional and Enhanced Field Listing for Probability Sampling." Proceedings of the Joint Statistical Meetings, Survey Research Methods Section. American Statistical Association.

Poterba, James, and Andrew Samwick. 2003. "Taxation and Household Portfolio Composition: U.S. Evidence from the 1980s and 1990s." Journal of Public Economics 87(1): 5-38.

Piketty, Thomas. 2013. Capital in the Twenty-First Century. Cambridge, MA: Belknap Press.

Stiglitz, Joseph E. 2012. The Price of Inequality: How Today's Divided Society Endangers Our Future. New York, NY: W.W. Norton. 
Saez, Emmanuel, and Gabriel Zucman. 2016. "Wealth Inequality in the United States since 1913: Evidence from Capitalized Income Tax Data." Quarterly Journal of Economics 131(2): 519-578.

Tourangeau, Roger, Robert A. Johnson, Jiahe Qian, Hee-Choon Shin, and Martin R. Frankel. 1993. "Selection of NORC's 1990 National Sample." 
Figure 1. SCF and FA assets

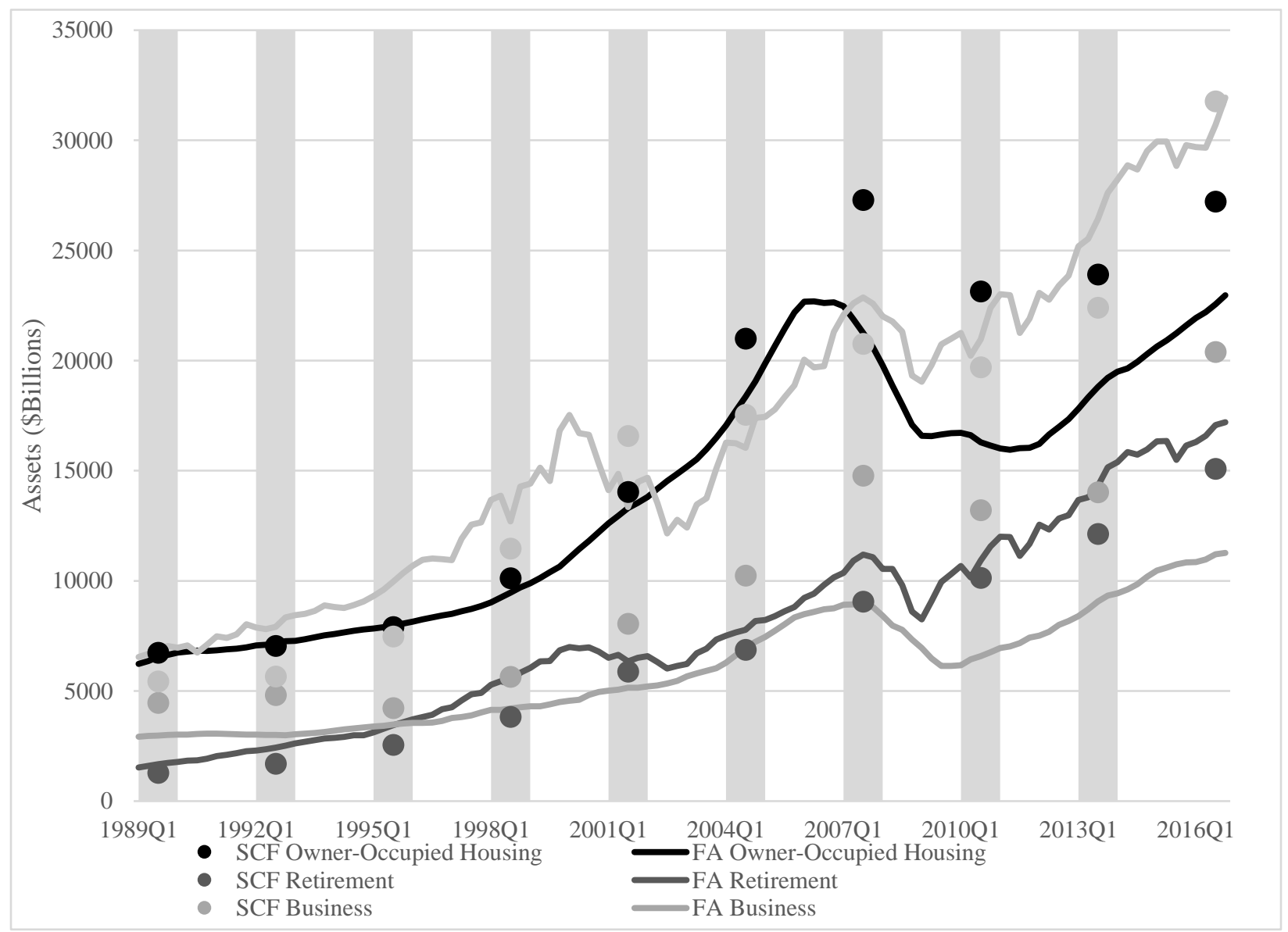


Figure 2. Average composition of household assets

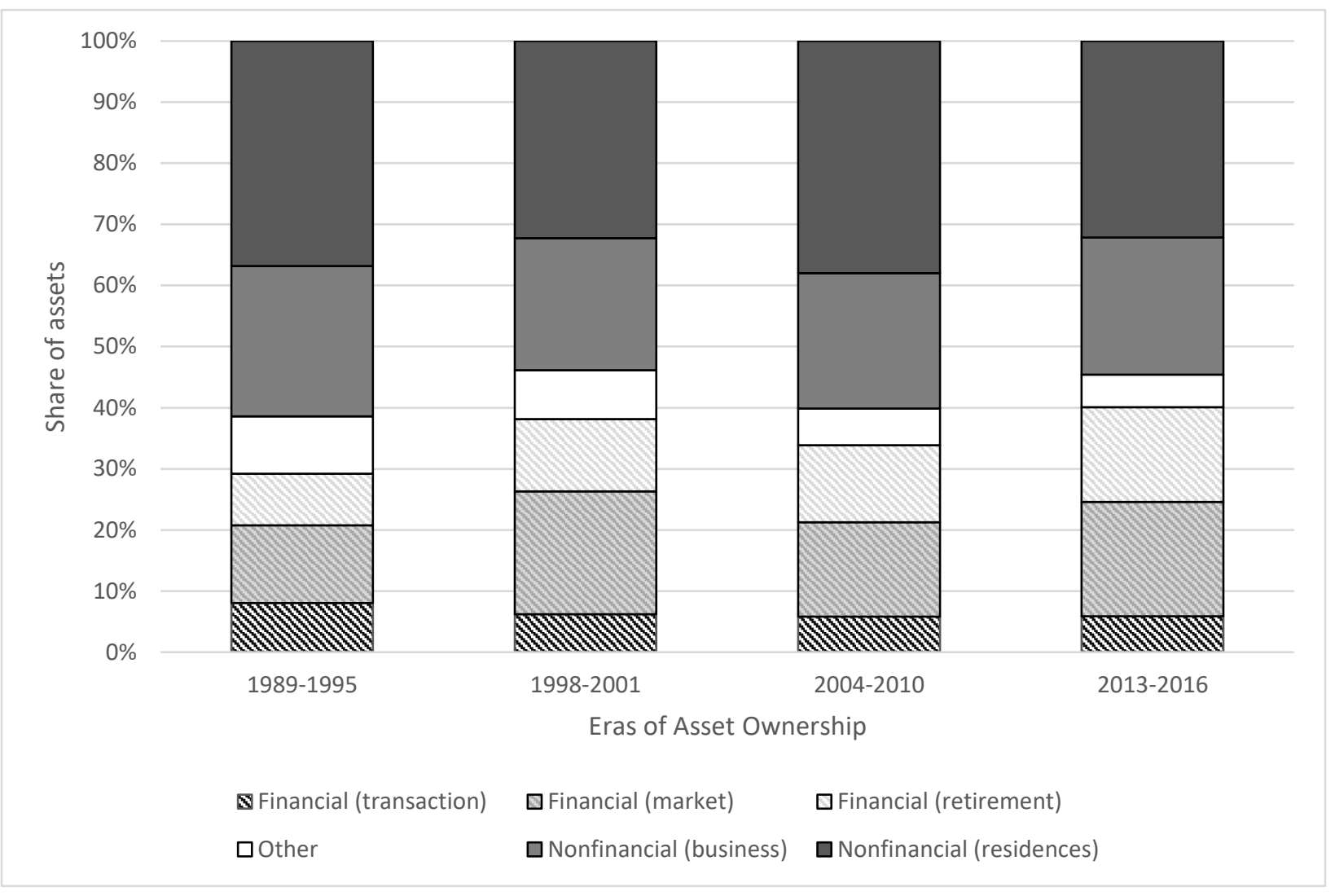


Figure 3. Share of assets in household asset portfolios: 2016 and 1989
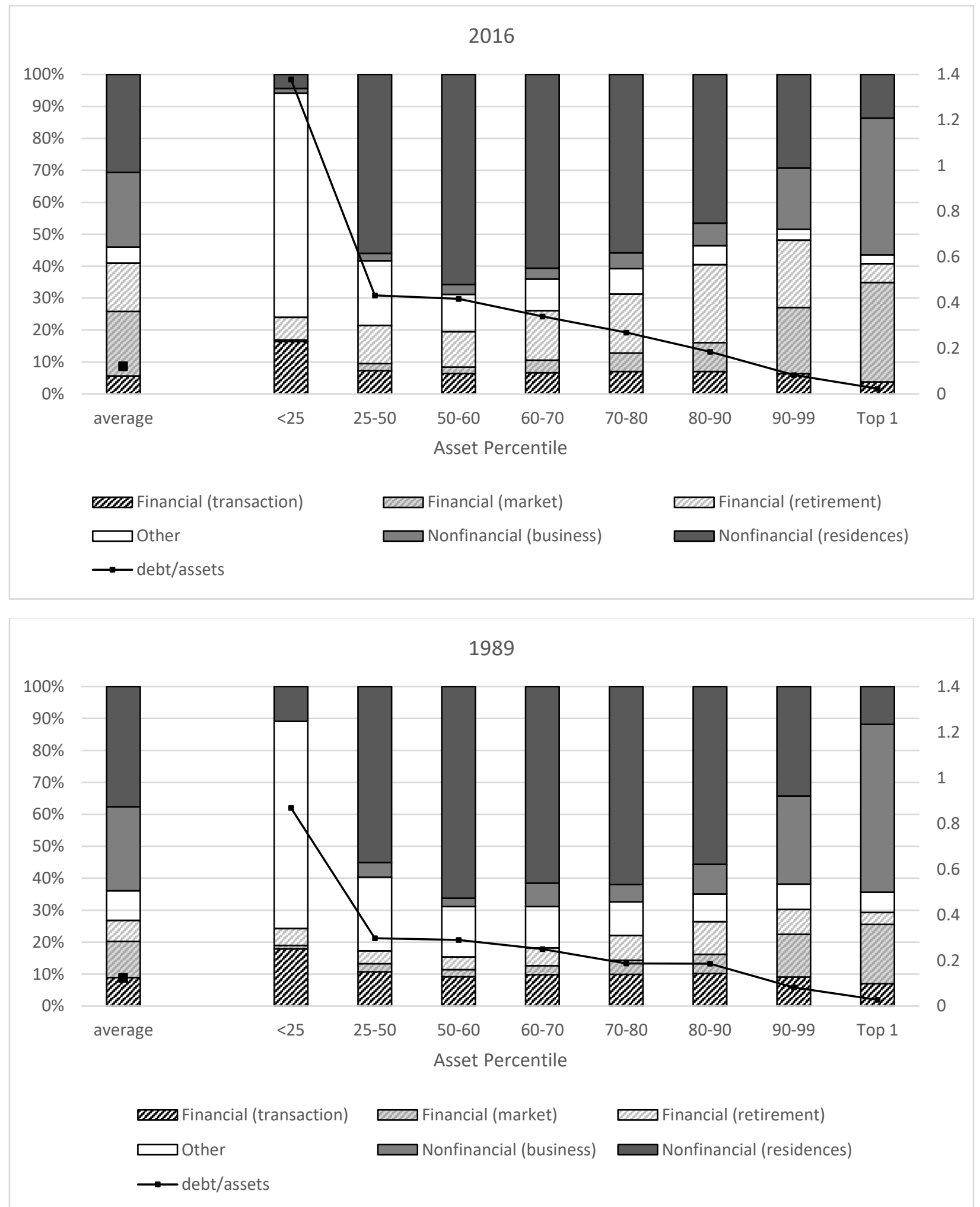
Figure 4. Share of assets in housing: average and at various percentiles, 1989-2016

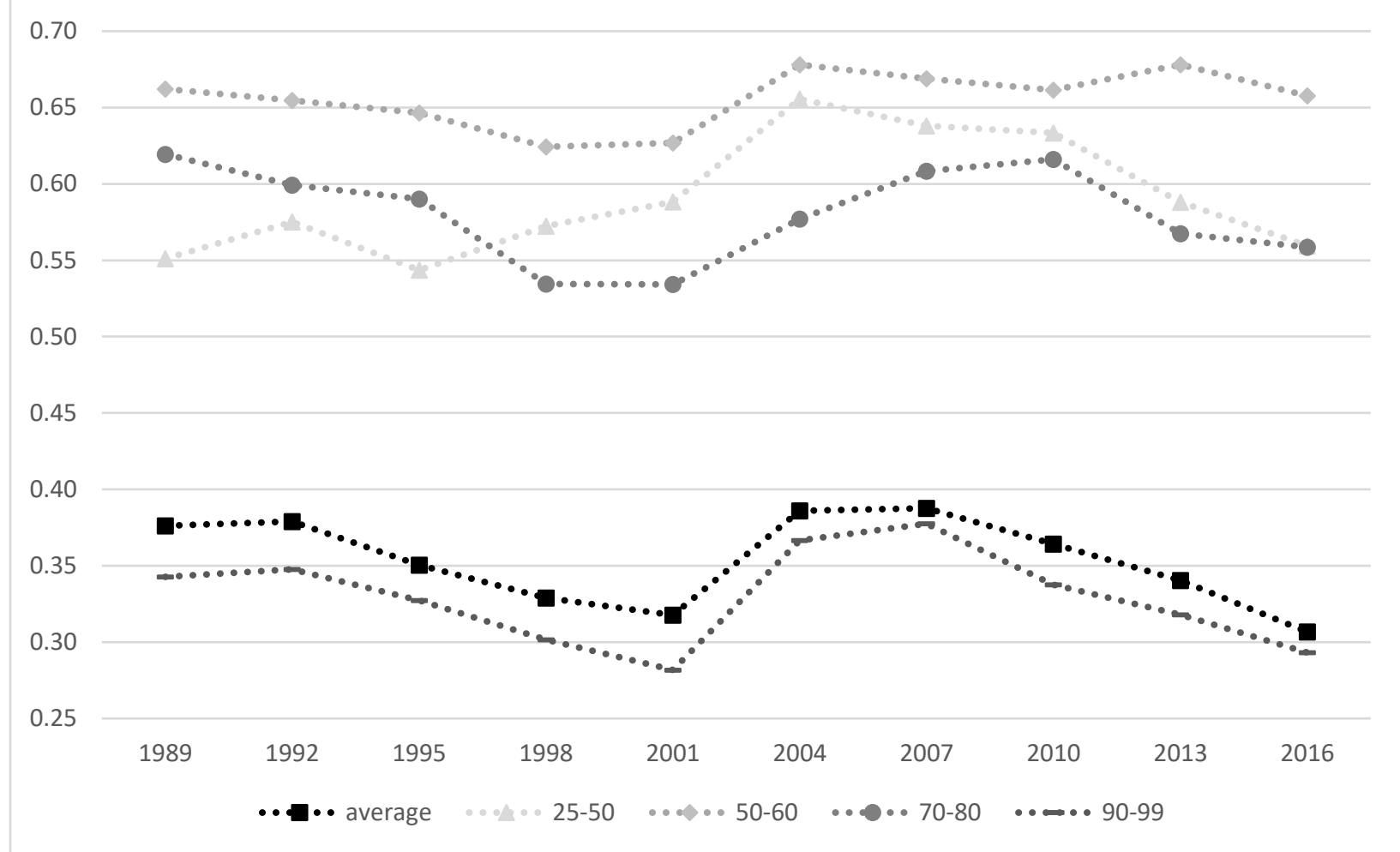

Figure 5. Share of assets in financial markets: average and at various percentiles, 1989-2016

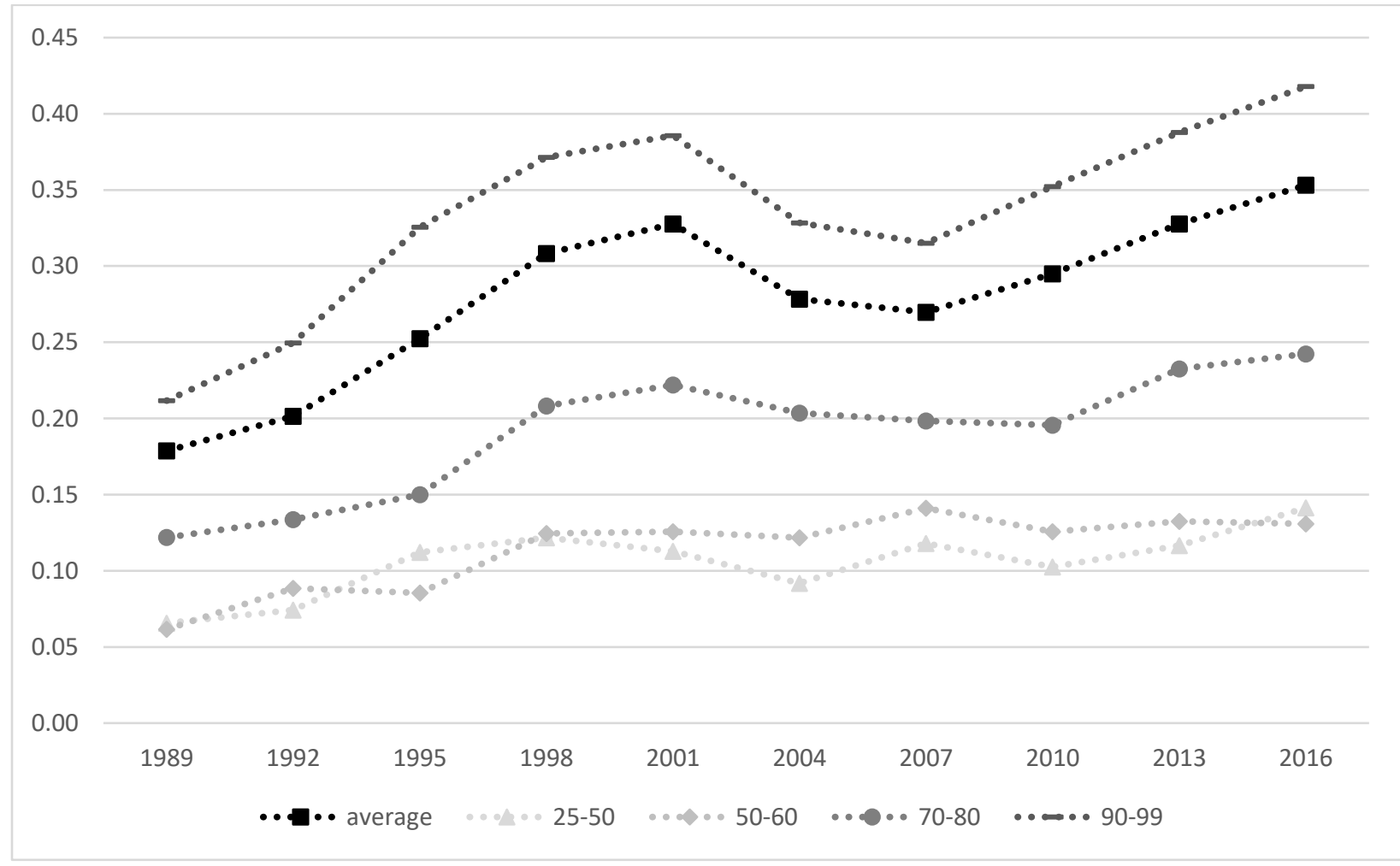


Figure 6. Share of assets that are unrealized capital gains: average and at various percentiles, 1989-2016

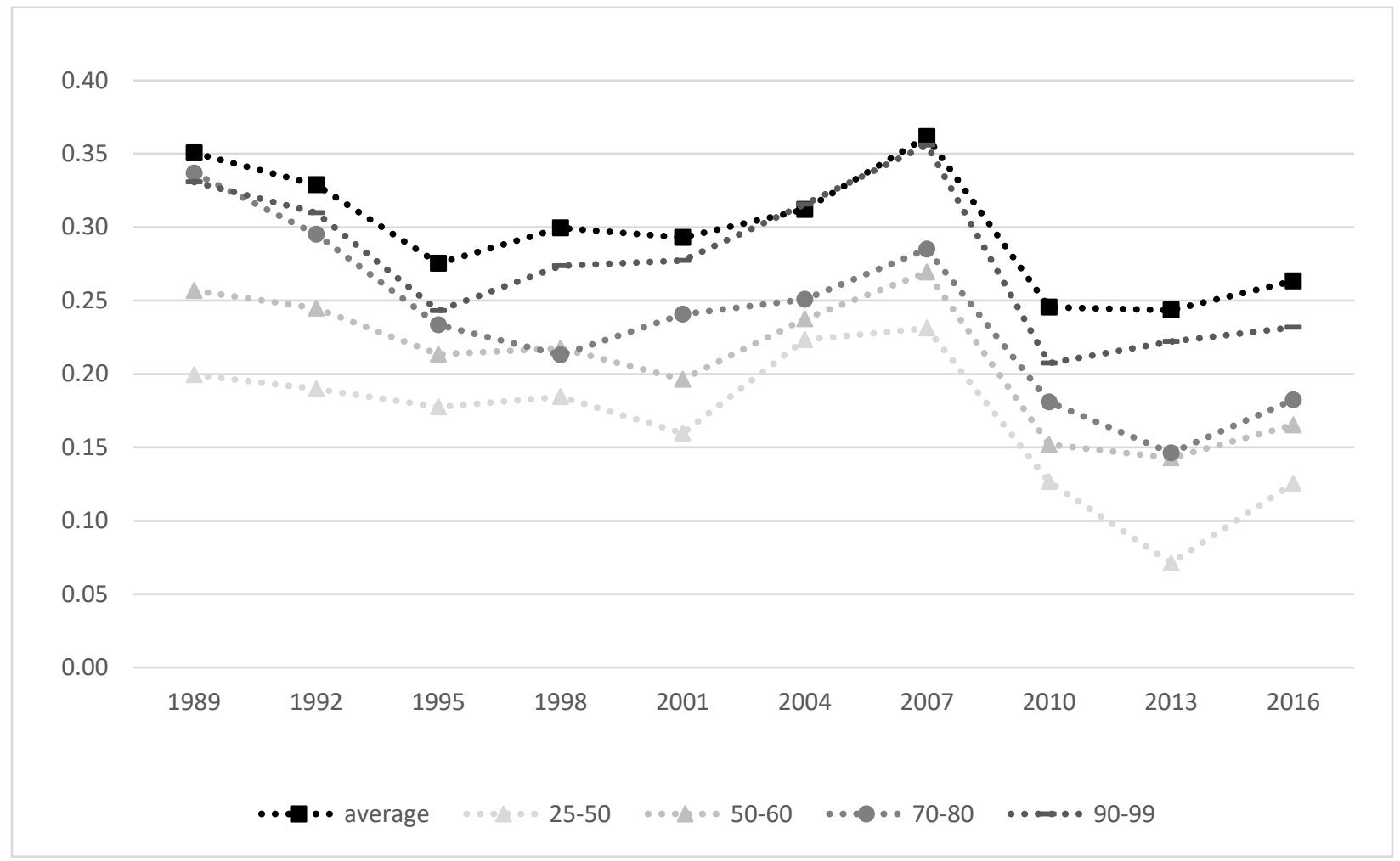

Figure 7. Share of assets held by asset percentile group, 1989-2016

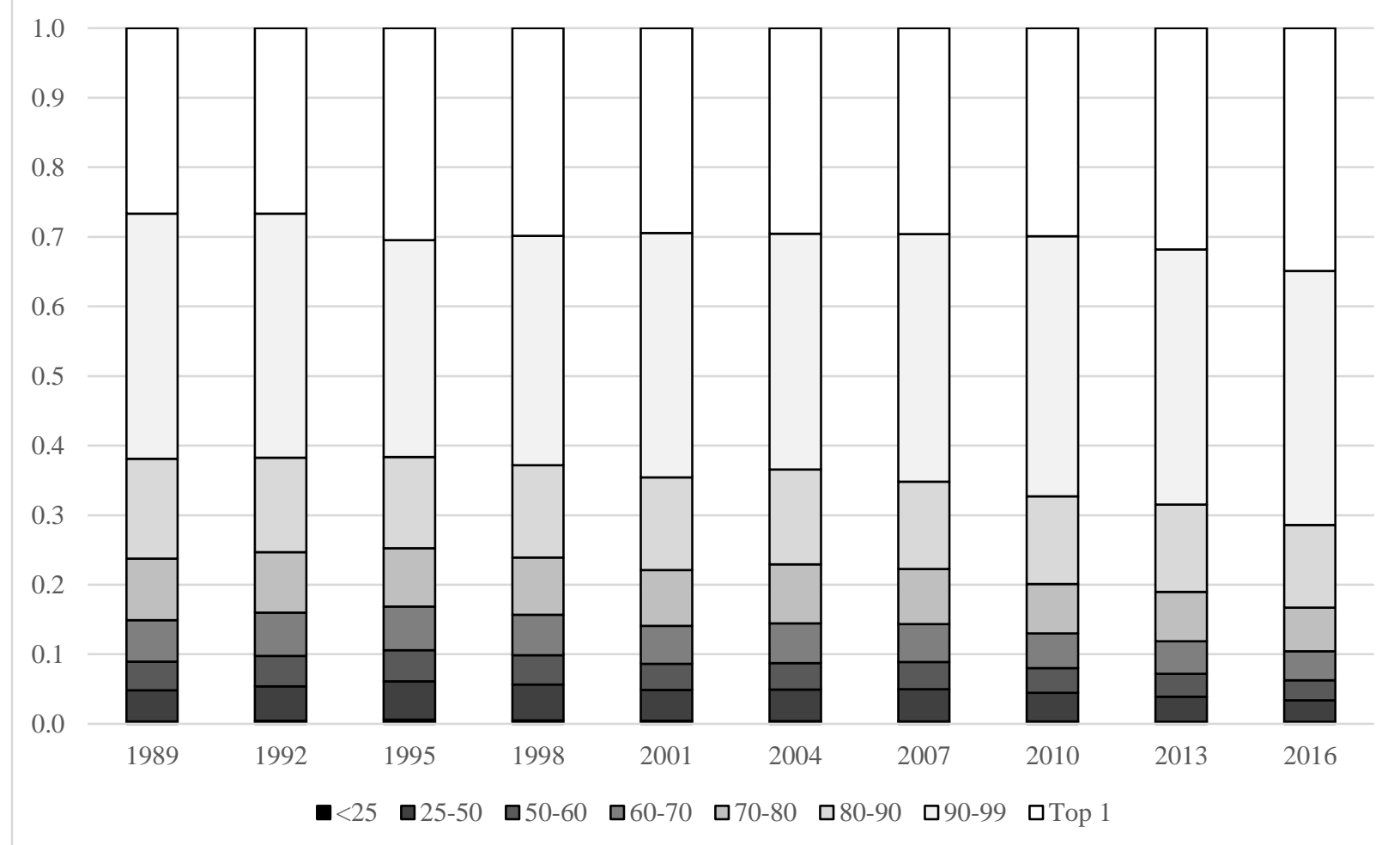


Figure 8. Share of assets held by age group, 1989-2016

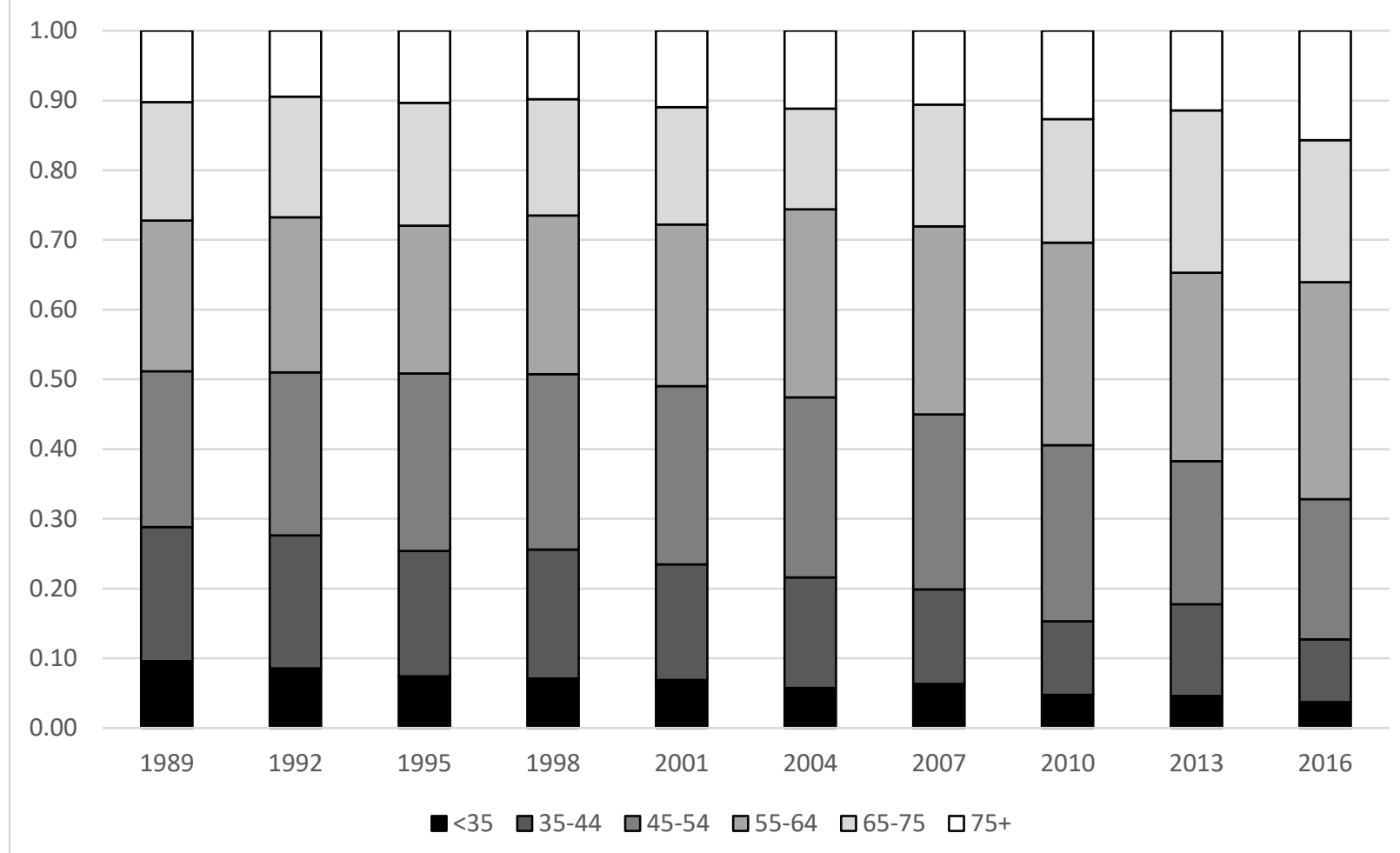

Figure 9. Median assets (Log10) by birth-year/normal-income cohort

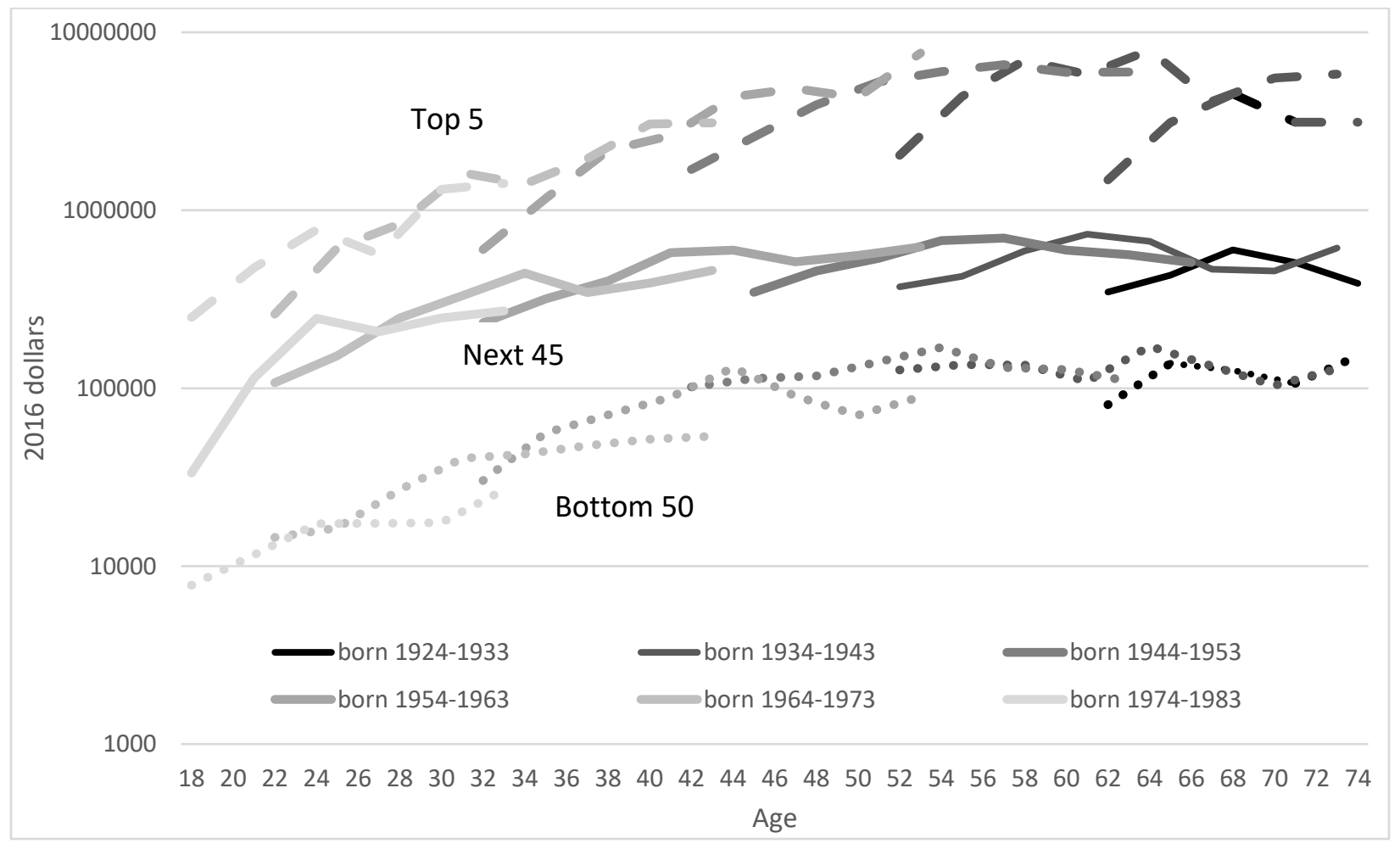


Figure 10. Share with business assets by birth-year/normal-income cohort

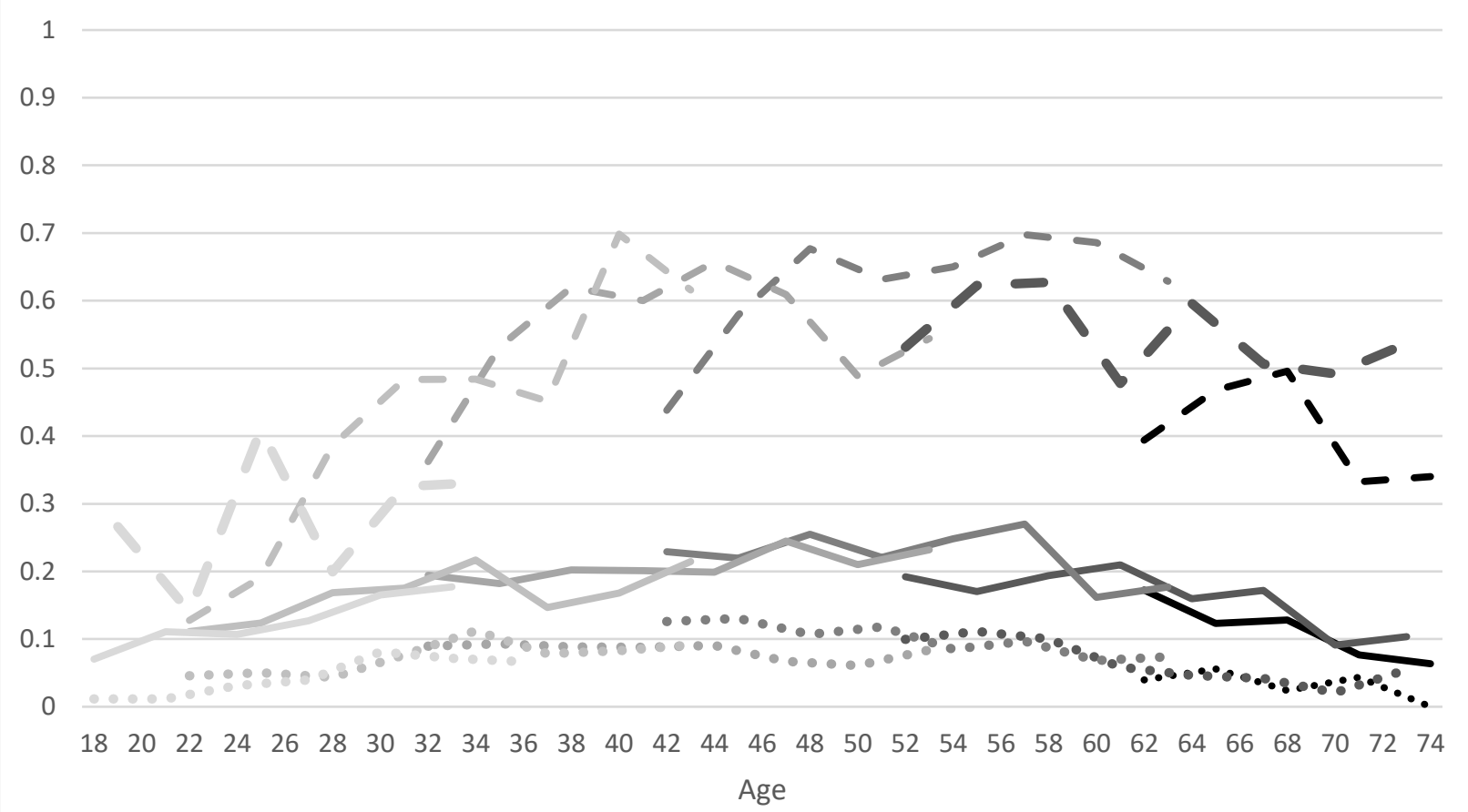

Figure 11. Share with equity by birth-year/normal-income cohort

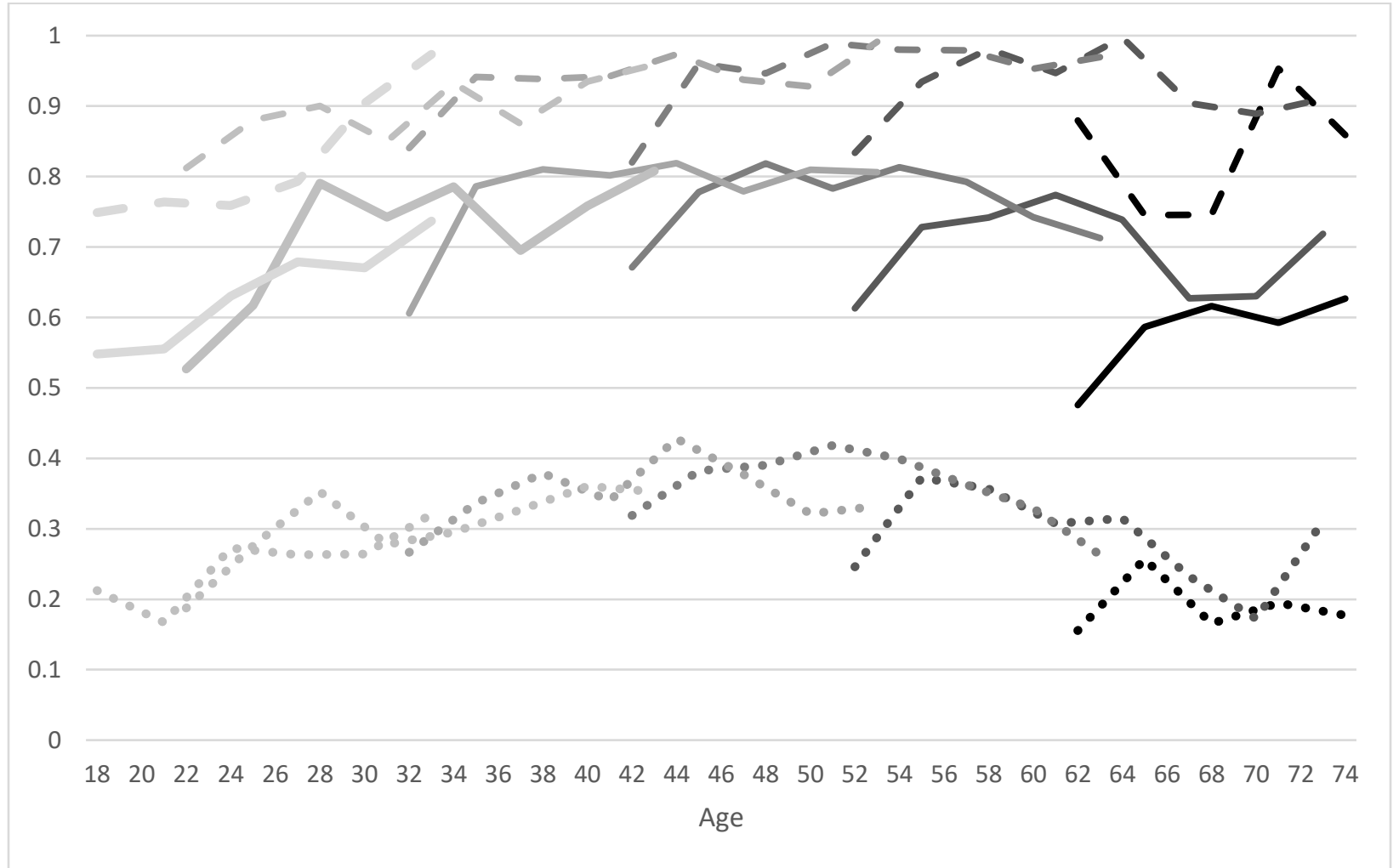


Figure 12. Homeowner share by birth-year/normal-income cohort

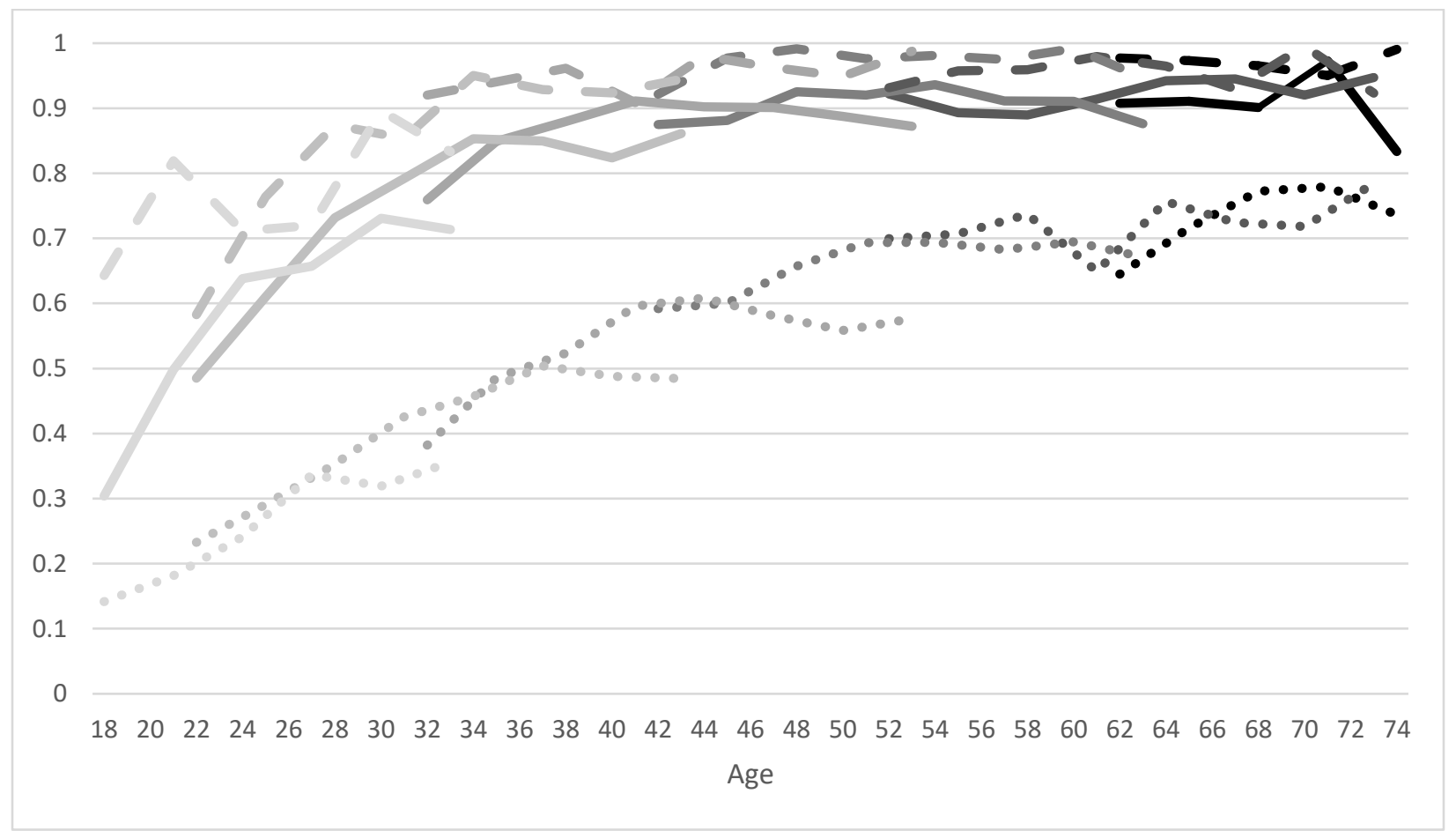

Figure 13. Share with mortgage on primary residence by birth-year/normal-income cohort

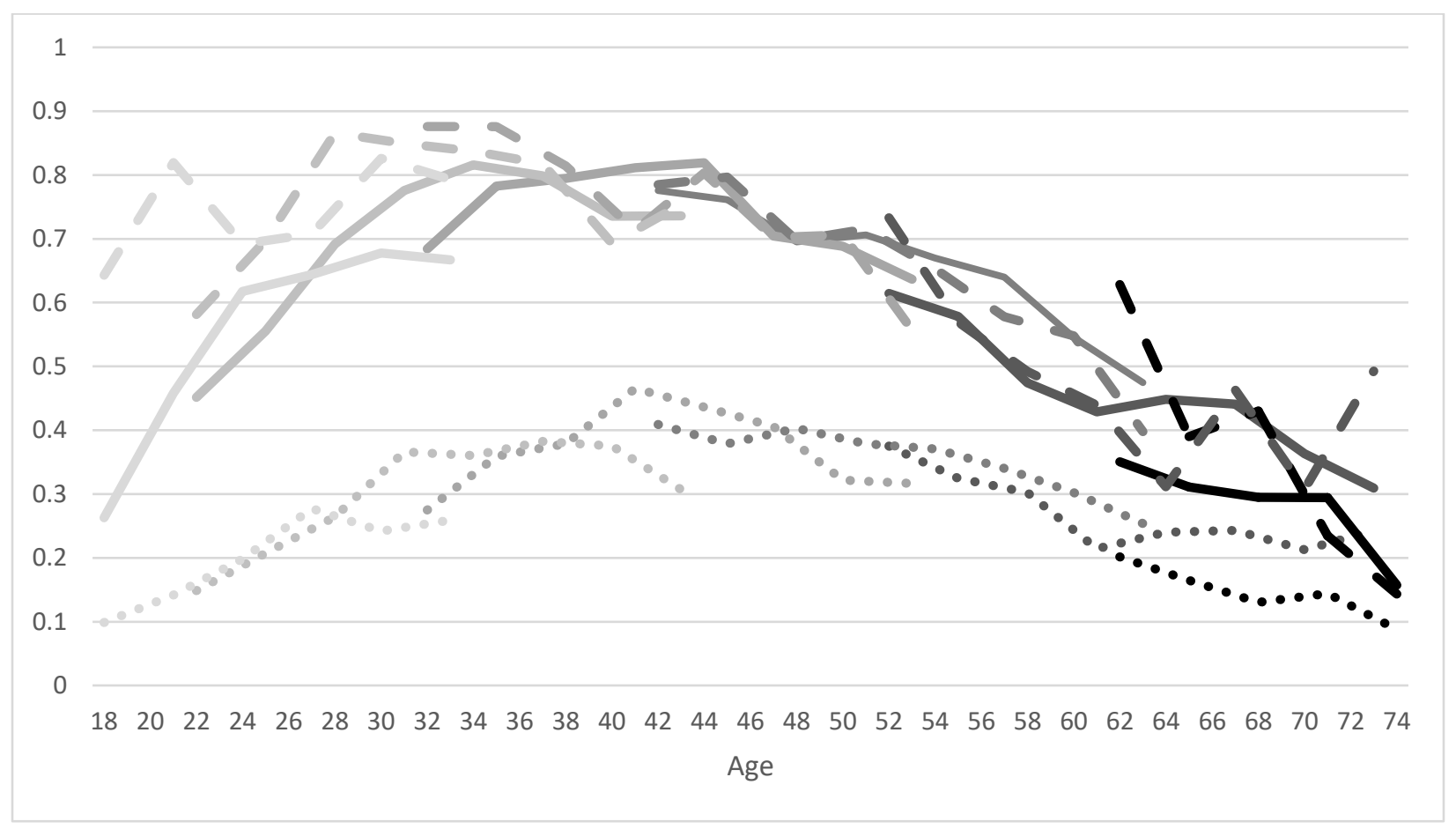


Figure 14. Business share of total assets by birth-year/normal-income cohort

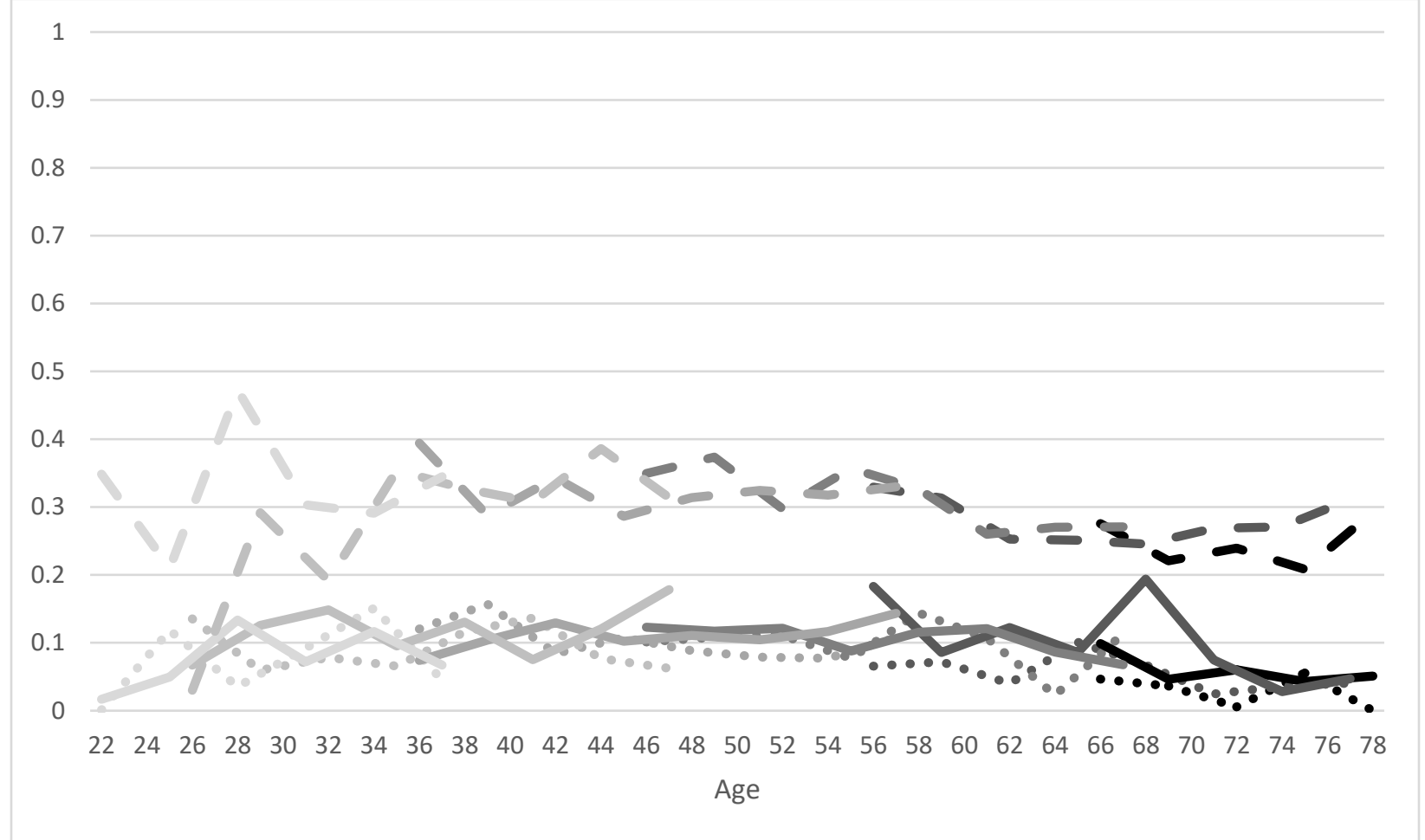

Figure 15. Equity share of total assets by birth-year/normal-income cohort

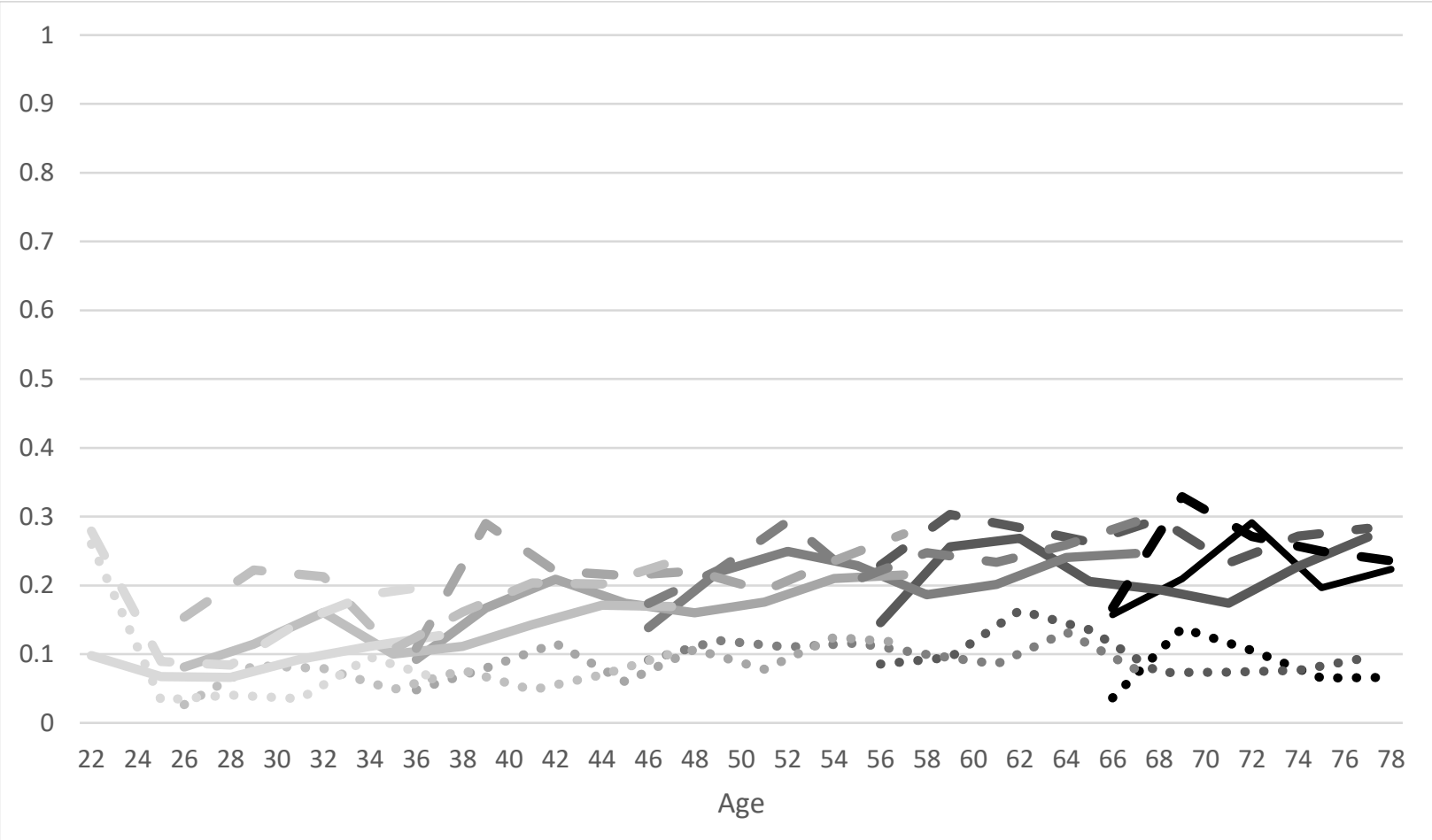


Figure 16. House value share of total assets by birth-year/normal-income cohort

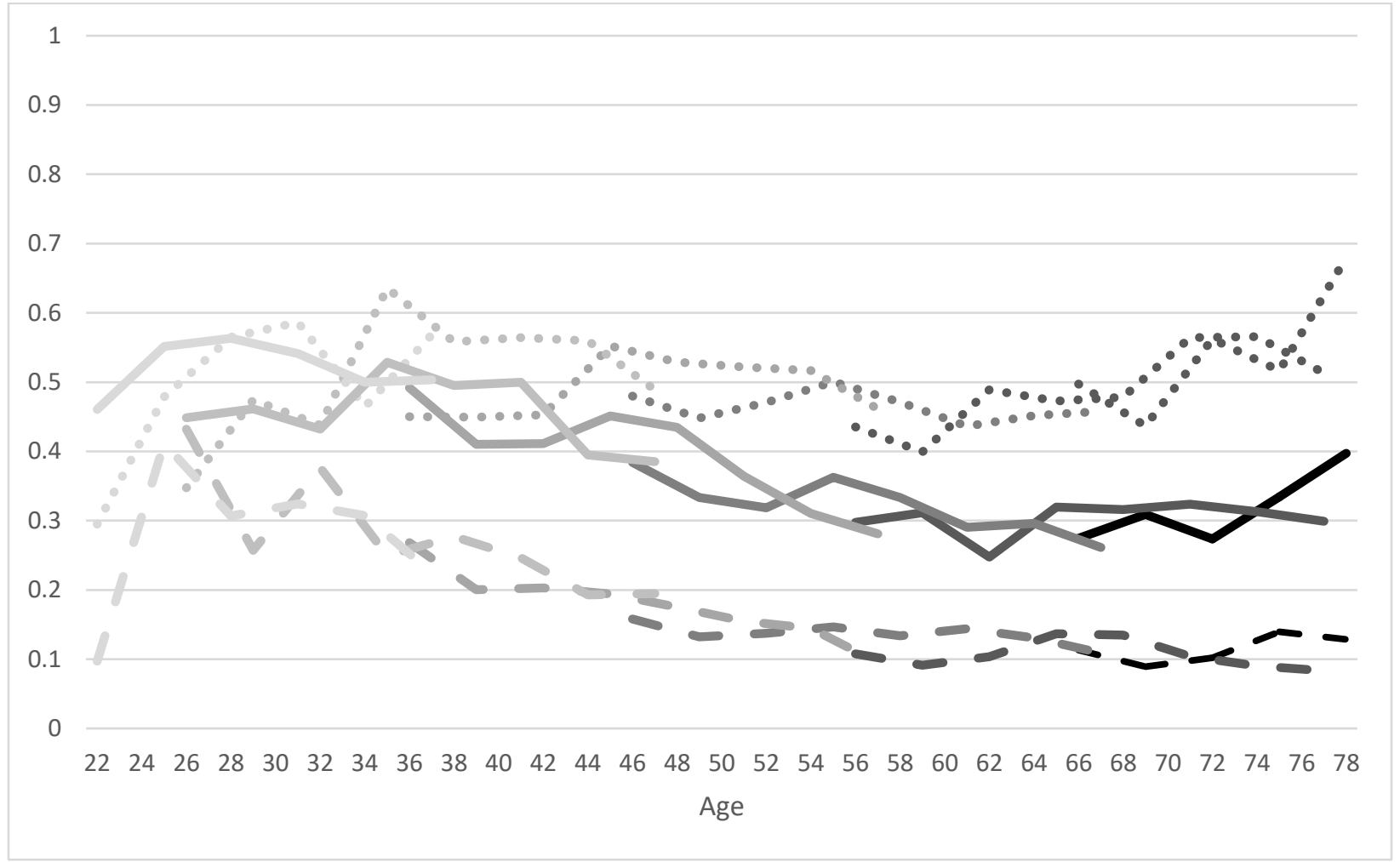

Figure 17. Combined "risky asset" Share of total assets by birth-year/normal-income cohort

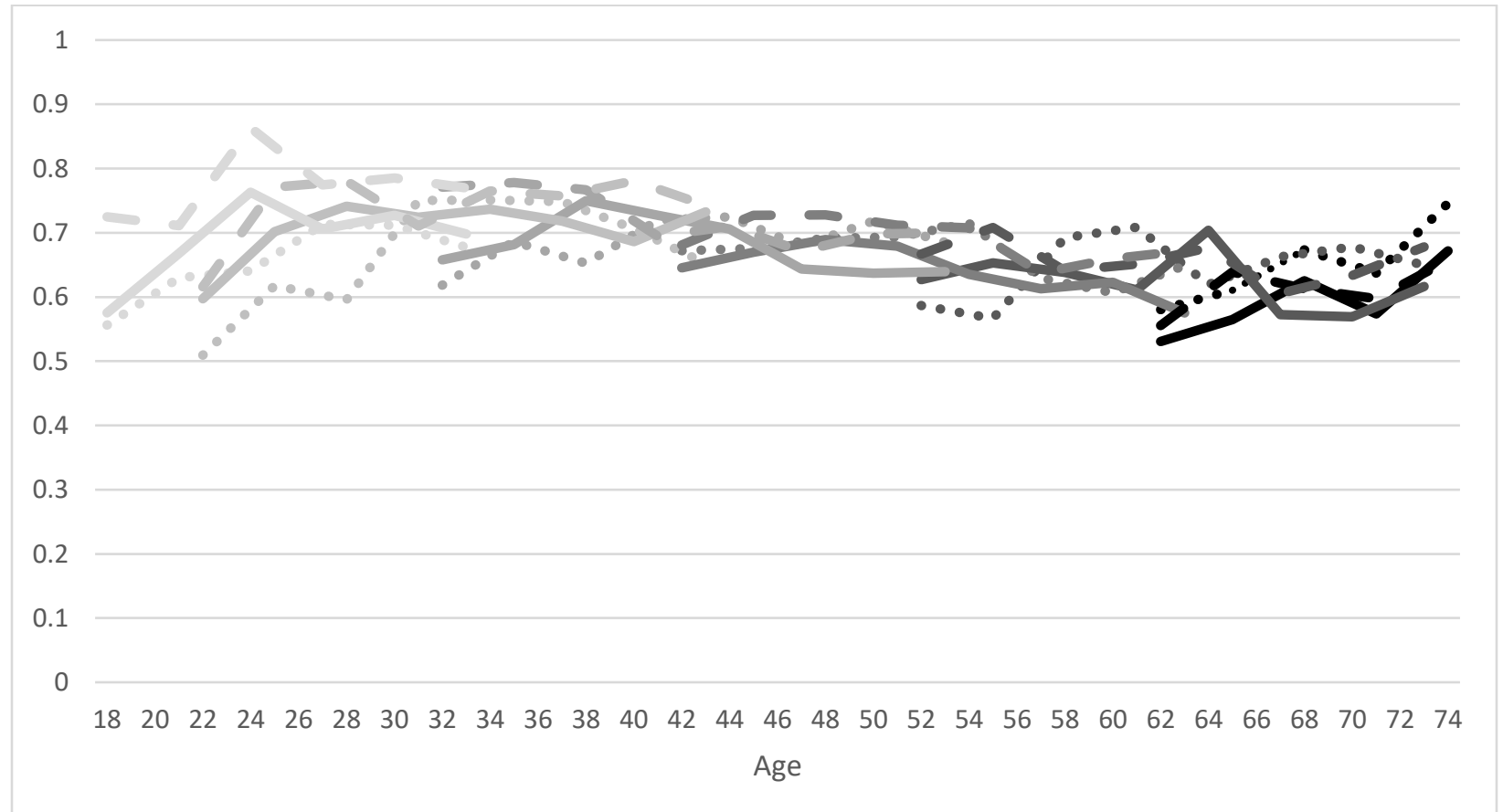


Figure 18. PIR and LTV 2016 SCF

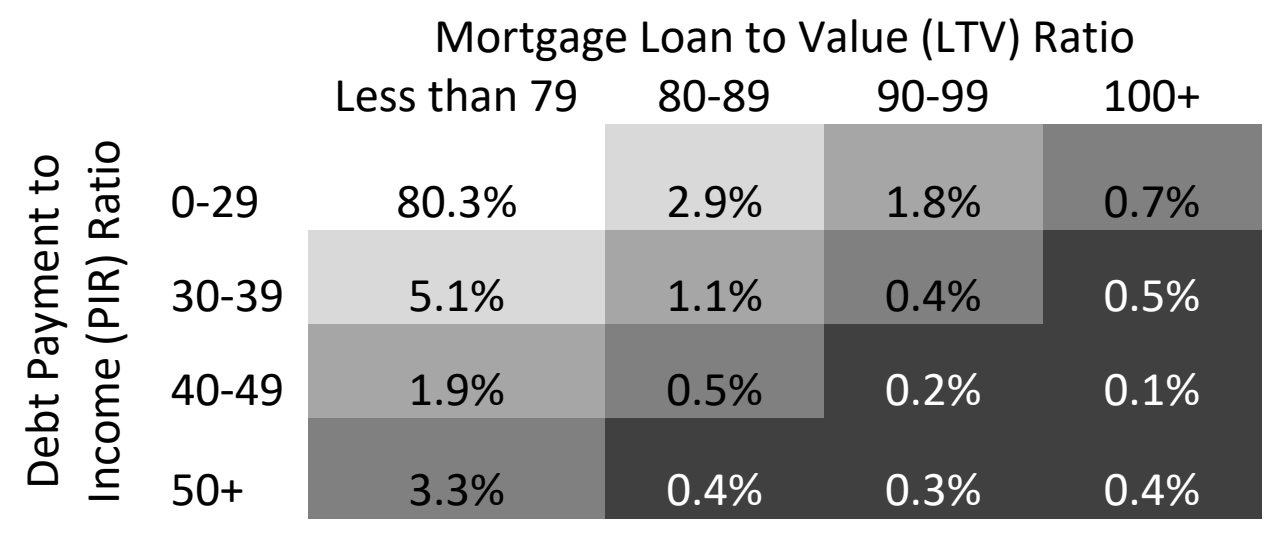


Figure 19. PIR and LTV across time

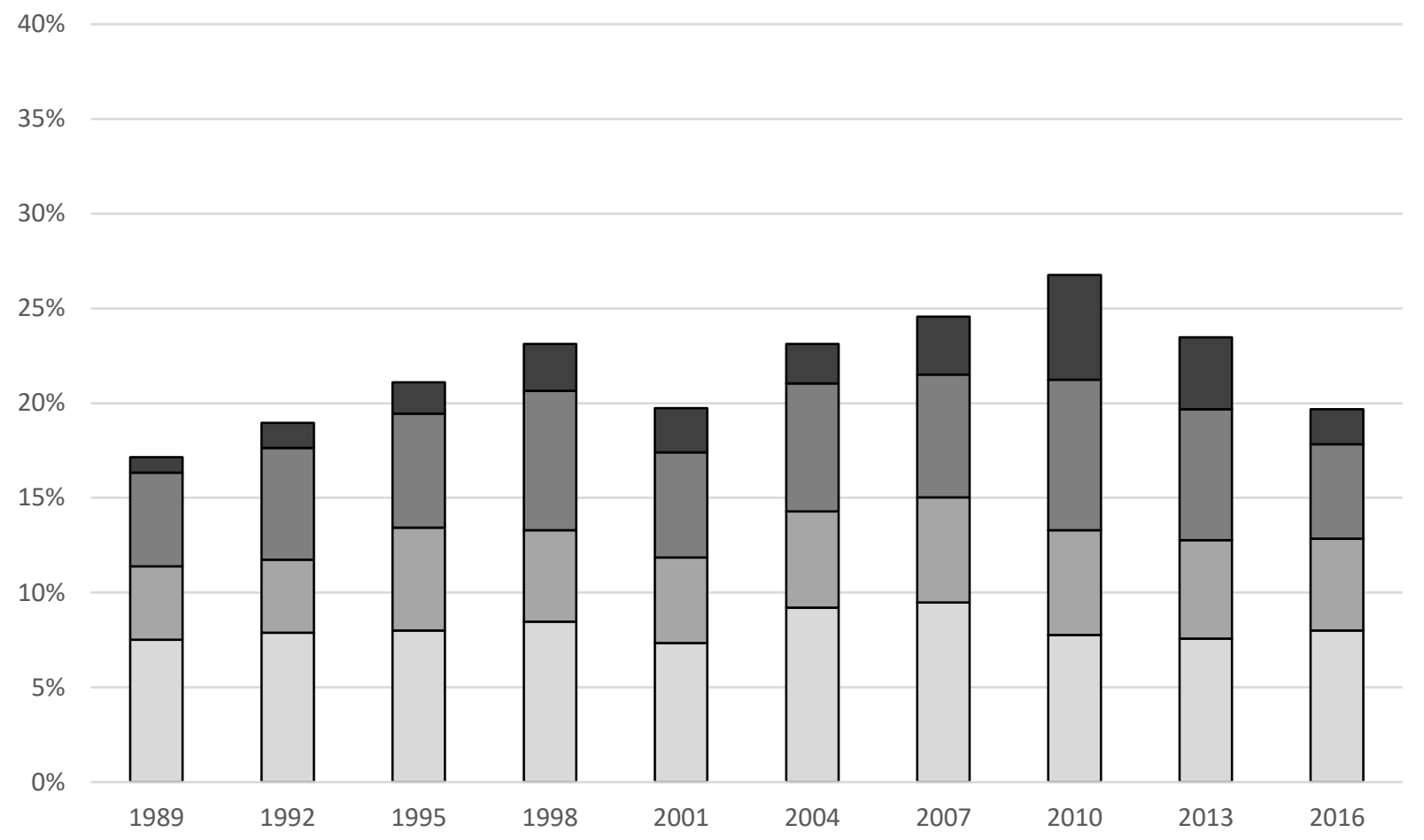

Figure 20. PIR and LTV across time, bottom 50 percent of usual income

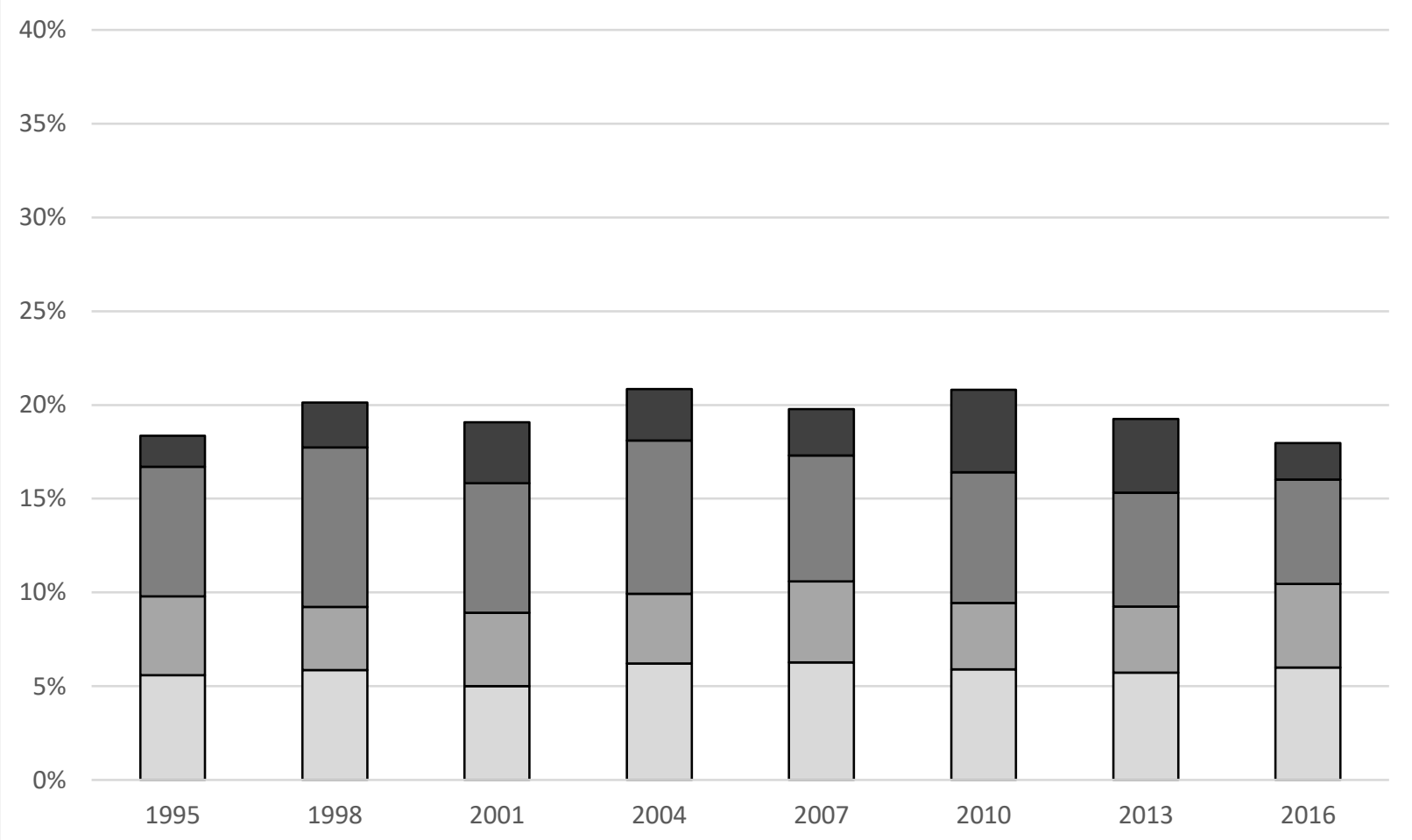


Figure 21. PIR and LTV across time, $51^{\text {st }}$ through $95^{\text {th }}$ percentiles of usual income

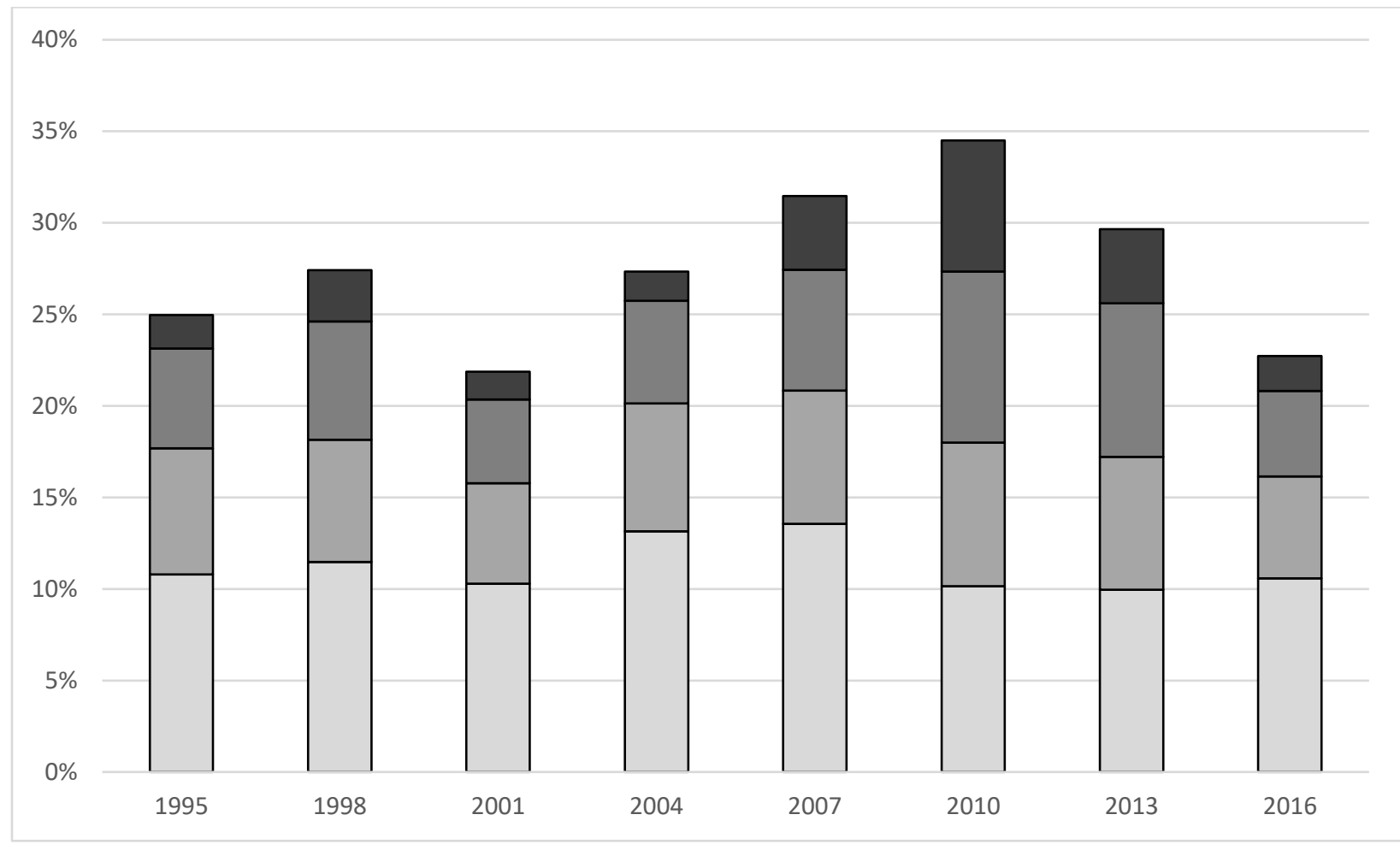

Figure 22. PIR and LTV across time, top 5 percent of usual income

$40 \%$

$35 \%$

$30 \%$

$25 \%$

$20 \%$

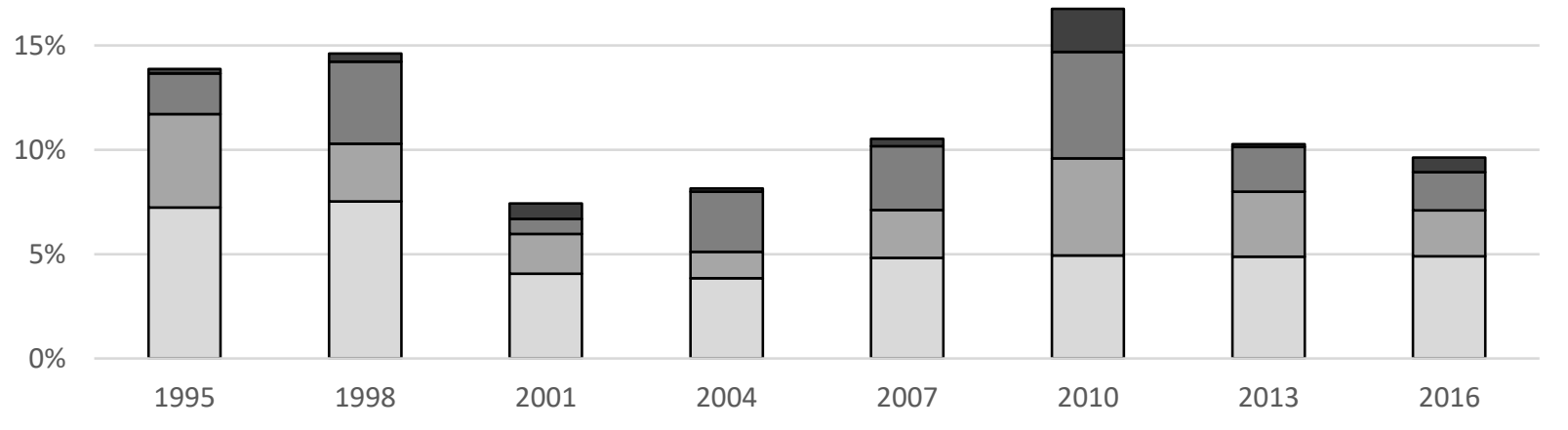


Figure 23. Percent with college degree by birth-year/normal-income cohort

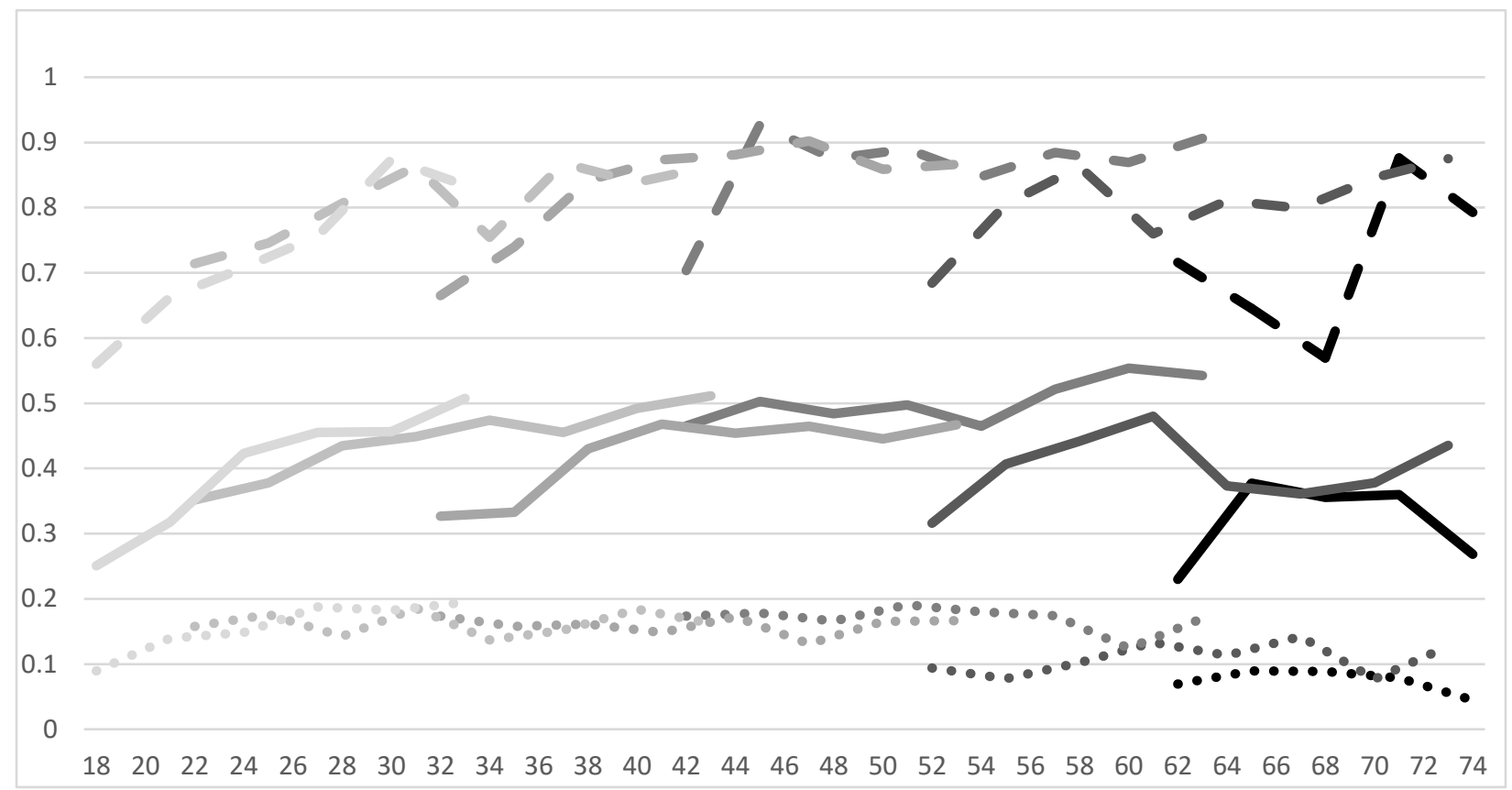

Figure 24. Average years of education by birth-year/normal-income cohort

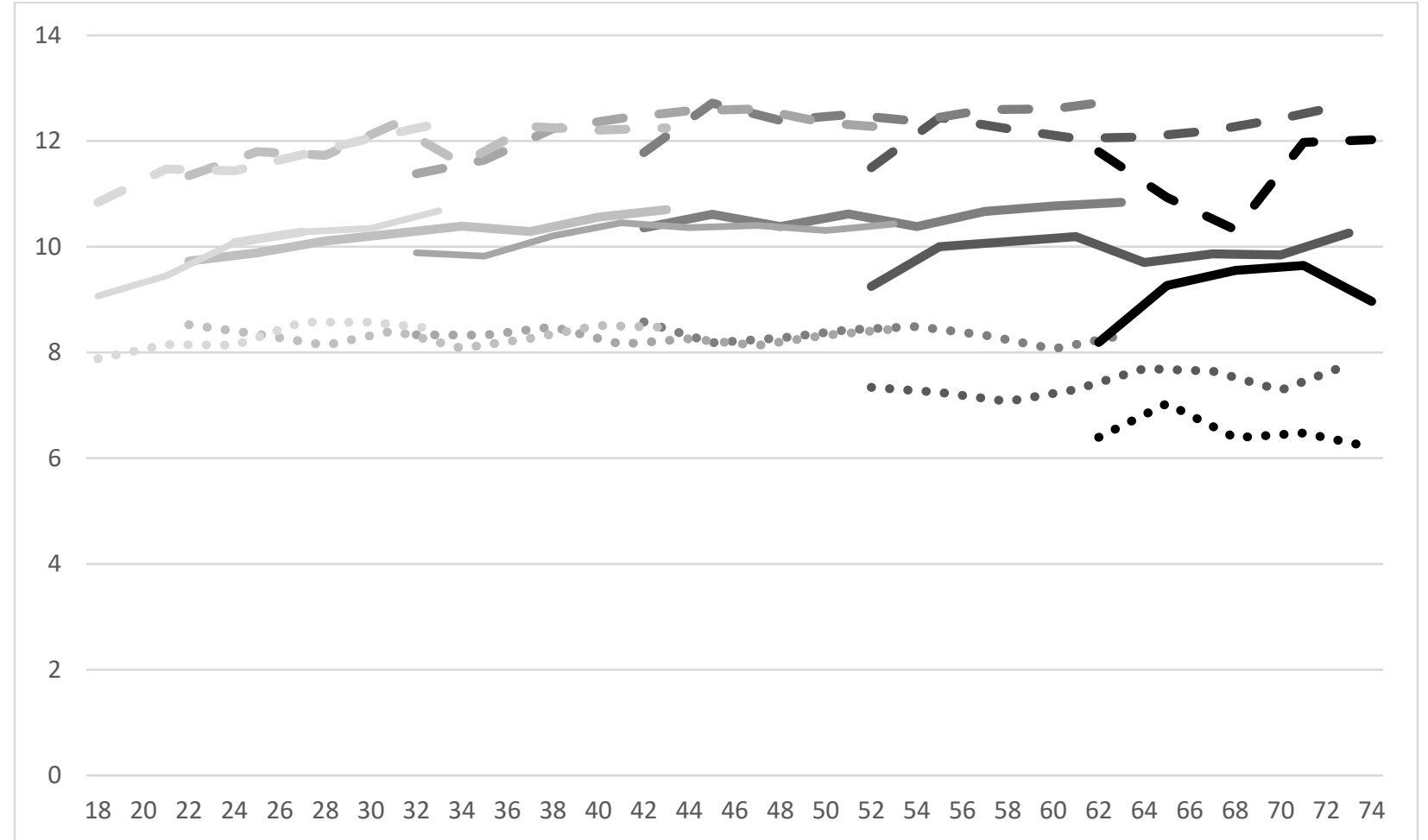


Appendix Figure 1. Share of debt, by asset percentile groups

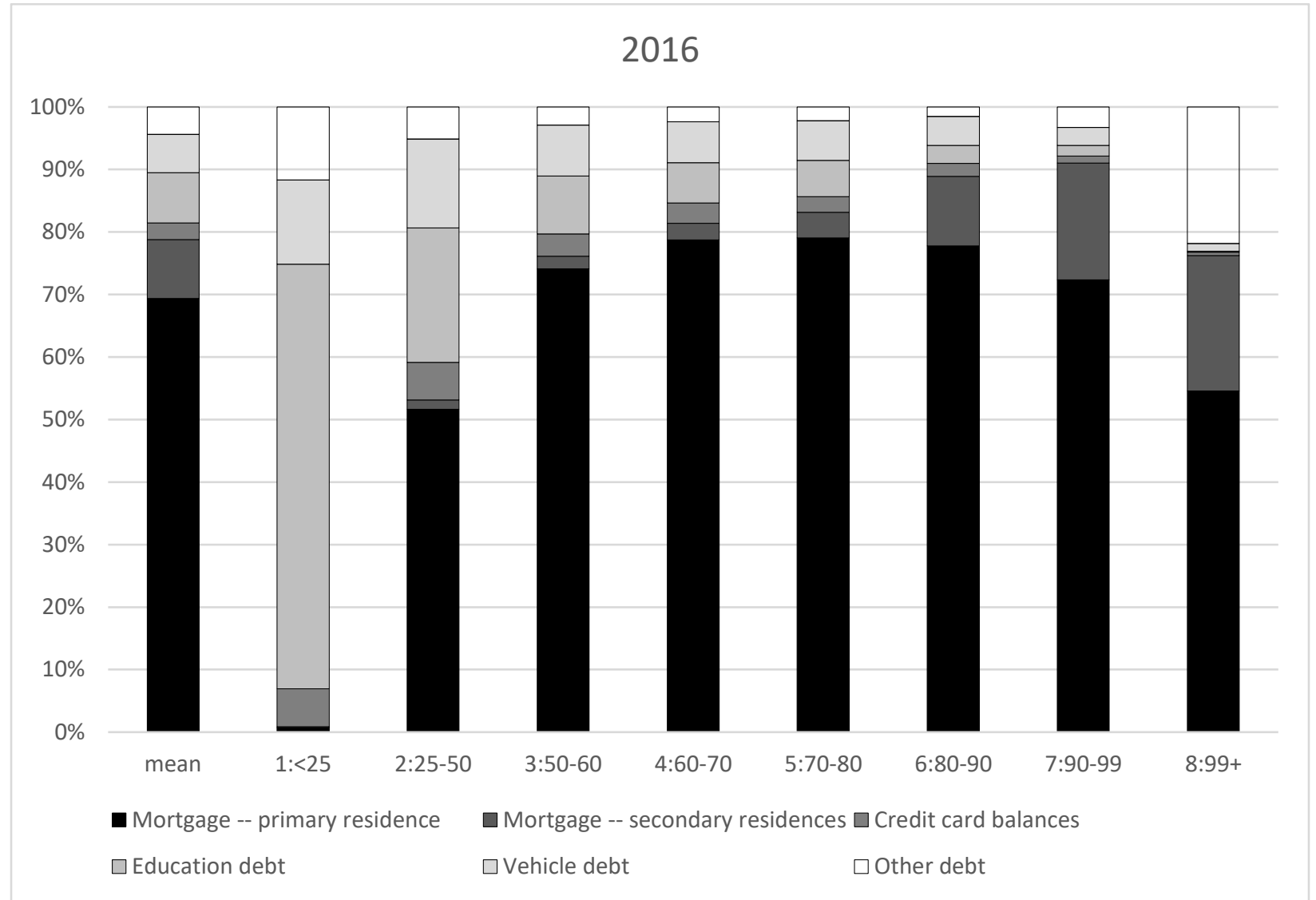


Table 1. Percent of families that hold assets, 1989-2016

\begin{tabular}{|c|c|c|c|c|c|c|c|c|c|c|}
\hline & 1989 & 1992 & 1995 & 1998 & 2001 & 2004 & 2007 & 2010 & 2013 & 2016 \\
\hline Any asset & 94.7 & 95.8 & 96.4 & 96.8 & 96.7 & 97.9 & 97.7 & 97.4 & 97.9 & 99.4 \\
\hline Financial asset & 88.9 & 90.3 & 91.2 & 93.1 & 93.4 & 93.8 & 93.9 & 94.0 & 94.5 & 98.5 \\
\hline Liquid asset & 85.5 & 86.9 & 87.4 & 90.6 & 91.4 & 91.3 & 92.1 & 92.5 & 93.2 & 98.0 \\
\hline CDs & 19.9 & 16.7 & 14.3 & 15.3 & 15.7 & 12.7 & 16.1 & 12.2 & 7.8 & 6.5 \\
\hline Mutual fund (dir.) & 7.2 & 10.4 & 12.3 & 16.5 & 17.7 & 15.0 & 11.4 & 8.7 & 8.2 & 10.0 \\
\hline Stocks (dir.) & 16.8 & 17.0 & 15.2 & 19.2 & 21.3 & 20.7 & 17.9 & 15.1 & 13.8 & 13.9 \\
\hline Bonds (dir.) & 5.7 & 4.3 & 3.1 & 3.0 & 3.0 & 1.8 & 1.6 & 1.6 & 1.4 & 1.2 \\
\hline $\begin{array}{l}\text { Managed acct. } \\
\text { DC pension or }\end{array}$ & 3.6 & 4.0 & 3.9 & 5.9 & 6.6 & 7.3 & 5.8 & 5.7 & 5.2 & 5.5 \\
\hline IRA & 37.1 & 40.1 & 45.3 & 48.9 & 52.8 & 49.9 & 53.0 & 50.4 & 49.2 & 52.1 \\
\hline $\begin{array}{c}\text { Other financial } \\
\text { Memo: }\end{array}$ & 55.0 & 51.2 & 50.0 & 45.1 & 43.7 & 41.5 & 38.5 & 33.1 & 30.7 & 30.9 \\
\hline $\begin{array}{l}\text { Equity (dir. or } \\
\text { indir.) } \\
\text { Directly held }\end{array}$ & 31.8 & 36.9 & 40.5 & 48.9 & 53.0 & 50.3 & 53.2 & 49.9 & 48.8 & 51.9 \\
\hline equity & 19.9 & 21.1 & 22.3 & 27.6 & 29.9 & 27.7 & 23.8 & 19.4 & 18.2 & 19.7 \\
\hline Non-financial & 89.3 & 90.8 & 90.9 & 89.9 & 90.7 & 92.5 & 92.0 & 91.3 & 91.0 & 90.8 \\
\hline Primary residence & 63.9 & 63.9 & 64.7 & 66.2 & 67.7 & 69.1 & 68.6 & 67.3 & 65.2 & 63.7 \\
\hline Second+ home & 13.1 & 12.7 & 11.8 & 12.8 & 11.3 & 12.5 & 13.8 & 14.3 & 13.2 & 13.8 \\
\hline Business & 21.1 & 20.8 & 19.2 & 18.7 & 19.0 & 19.1 & 19.0 & 18.5 & 16.7 & 17.4 \\
\hline Other nonfin. & 84.5 & 86.4 & 85.0 & 83.6 & 85.5 & 87.0 & 87.7 & 87.2 & 86.8 & 85.8 \\
\hline Any debt & 72.3 & 73.2 & 74.5 & 74.1 & 75.1 & 76.4 & 77.0 & 74.9 & 74.5 & 77.1 \\
\hline $\begin{array}{l}\text { Mortgage } \\
\text { Mortg. }\left(2^{\text {nd }}+\right.\end{array}$ & 39.5 & 39.1 & 41.0 & 43.1 & 44.6 & 47.9 & 48.7 & 47.0 & 42.9 & 41.9 \\
\hline $\begin{array}{l}\text { home) } \\
\text { Credit card }\end{array}$ & 5.1 & 5.7 & 4.7 & 5.0 & 4.6 & 4.0 & 5.5 & 5.3 & 5.2 & 5.6 \\
\hline balance & 39.7 & 43.7 & 47.3 & 44.1 & 44.4 & 46.2 & 46.1 & 39.4 & 38.1 & 43.9 \\
\hline Other installment & 52.5 & 50.2 & 50.3 & 48.5 & 48.5 & 49.8 & 49.8 & 49.2 & 50.0 & 52.4 \\
\hline
\end{tabular}


Table 2. Mean asset holdings, 1989-2016 (thousands of 2016 dollars)

\begin{tabular}{|c|c|c|c|c|c|c|c|c|c|c|}
\hline & 1989 & 1992 & 1995 & 1998 & 2001 & 2004 & 2007 & 2010 & 2013 & 2016 \\
\hline Any asset & 395.3 & 365.8 & 388.9 & 486.6 & 612.2 & 672.0 & 758.3 & 659.5 & 645.3 & 787.1 \\
\hline Financial asset & 120.6 & 115.7 & 143.0 & 198.2 & 258.3 & 240.9 & 257.9 & 250.1 & 263.0 & 334.7 \\
\hline Liquid asset & 23.0 & 20.1 & 19.9 & 22.5 & 29.4 & 31.6 & 28.2 & 33.2 & 34.9 & 39.4 \\
\hline CDs & 12.3 & 9.3 & 8.0 & 8.5 & 7.9 & 8.9 & 10.4 & 9.8 & 5.2 & 4.9 \\
\hline $\begin{array}{l}\text { Mutual fund } \\
\text { (dir.) }\end{array}$ & 6.4 & 8.8 & 18.1 & 24.6 & 31.3 & 35.2 & 40.8 & 37.4 & 39.0 & 77.8 \\
\hline Stocks (dir.) & 18.1 & 19.0 & 22.3 & 44.9 & 55.5 & 42.1 & 45.9 & 35.1 & 41.7 & 45.7 \\
\hline Bonds (dir.) & 12.3 & 9.7 & 8.9 & 8.5 & 11.7 & 12.7 & 10.7 & 11.1 & 8.5 & 9.4 \\
\hline $\begin{array}{l}\text { Managed acct. } \\
\text { DC pension or }\end{array}$ & 7.9 & 6.3 & 8.4 & 16.9 & 27.2 & 19.1 & 16.8 & 15.5 & 19.9 & 25.8 \\
\hline IRA & 26.0 & 29.9 & 40.5 & 55.1 & 74.9 & 78.1 & 90.4 & 95.4 & 102.2 & 119.2 \\
\hline $\begin{array}{c}\text { Other financial } \\
\text { Memo: }\end{array}$ & 14.8 & 12.5 & 16.9 & 17.2 & 20.5 & 13.4 & 14.9 & 12.6 & 11.6 & 12.4 \\
\hline $\begin{array}{l}\text { Equity (dir. or } \\
\text { indir.) }\end{array}$ & 33.6 & 39.2 & 57.4 & 107.1 & 147.1 & 123.8 & 139.3 & 117.5 & 135.9 & 178.7 \\
\hline $\begin{array}{l}\text { Non-financial } \\
\text { Primary }\end{array}$ & 274.7 & 250.2 & 245.9 & 288.3 & 353.8 & 431.1 & 500.4 & 409.4 & 382.2 & 452.4 \\
\hline residence & 126.3 & 117.5 & 116.7 & 135.5 & 165.8 & 216.8 & 240.4 & 194.4 & 176.4 & 191.9 \\
\hline Second+ home & 22.4 & 21.2 & 19.6 & 24.5 & 28.6 & 42.6 & 53.5 & 45.8 & 43.2 & 49.5 \\
\hline Business & 103.9 & 93.1 & 86.4 & 104.6 & 132.6 & 143.1 & 177.6 & 142.9 & 137.1 & 184.2 \\
\hline Other nonfin. & 22.2 & 18.4 & 23.2 & 23.6 & 26.8 & 28.6 & 28.9 & 26.4 & 25.5 & 26.9 \\
\hline Any debt & 48.4 & 52.9 & 56.8 & 69.2 & 73.8 & 100.5 & 112.4 & 108.2 & 94.0 & 95.1 \\
\hline Mortgage & 33.4 & 38.1 & 41.5 & 49.4 & 55.5 & 75.6 & 84.0 & 80.2 & 69.4 & 66.0 \\
\hline $\begin{array}{l}\text { Mortg. }\left(2^{\text {nd }}+\right. \\
\text { home }) \\
\text { Credit card }\end{array}$ & 3.7 & 5.4 & 4.3 & 5.2 & 4.6 & 8.5 & 11.4 & 10.6 & 8.4 & 9.0 \\
\hline $\begin{array}{l}\text { balance } \\
\text { Other }\end{array}$ & 1.4 & 1.7 & 2.2 & 2.7 & 2.5 & 3.0 & 3.9 & 3.1 & 2.3 & 2.5 \\
\hline installment & 9.9 & 7.6 & 8.7 & 11.9 & 11.2 & 13.4 & 13.1 & 14.4 & 13.9 & 17.6 \\
\hline $\begin{array}{l}\text { Memo: } \\
\text { Net worth }\end{array}$ & 346.9 & 312.9 & 332.1 & 417.3 & 538.4 & 571.5 & 645.9 & 551.3 & 551.3 & 692.0 \\
\hline
\end{tabular}


Table 3. Average assets and debts of asset groups, 1989-2016 (in thousands of 2016 dollars)

\begin{tabular}{|c|c|c|c|c|c|c|c|c|c|c|}
\hline \multirow{2}{*}{$\begin{array}{l}\text { Asset } \\
\text { percentile }\end{array}$} & \multicolumn{2}{|c|}{2016} & \multicolumn{2}{|c|}{2013} & \multicolumn{2}{|c|}{2010} & \multicolumn{2}{|c|}{2007} & \multicolumn{2}{|c|}{2004} \\
\hline & asset & debt & asset & debt & asset & debt & asset & debt & asset & debt \\
\hline$<25$ & 9.0 & 12.4 & 8.4 & 9.8 & 9.1 & 9.3 & 11.3 & 8.9 & 11.5 & 9.3 \\
\hline $25-50$ & 96.9 & 41.8 & 91.9 & 41.1 & 108.4 & 51.9 & 140.2 & 53.7 & 120.7 & 47.8 \\
\hline $50-60$ & 227.6 & 94.9 & 212.9 & 97.8 & 234.8 & 105.8 & 296.0 & 109.7 & 257.8 & 99.2 \\
\hline $60-70$ & 327.9 & 111.4 & 302.9 & 110.6 & 327.9 & 136.5 & 412.1 & 135.3 & 380.2 & 130.6 \\
\hline $70-80$ & 495.8 & 133.7 & 456.0 & 139.2 & 469.7 & 164.1 & 601.5 & 164.9 & 571.7 & 151.1 \\
\hline $80-90$ & 935.3 & 173.0 & 810.1 & 174.5 & 831.3 & 166.7 & 951.3 & 188.3 & 914.9 & 166.3 \\
\hline $90-99$ & 3,191.2 & 264.7 & $2,627.2$ & 257.5 & $2,740.1$ & 317.3 & $2,996.0$ & 335.6 & 2529.5 & 251.5 \\
\hline Top 1 & $27,448.8$ & 643.9 & $20,523.4$ & 587.2 & $19,674.0$ & 703.5 & $22,403.0$ & 669.6 & 19834.5 & 879.5 \\
\hline average & 787.1 & 95.1 & 645.3 & 94.0 & 659.5 & 108.2 & 758.3 & 112.4 & 672.0 & 100.5 \\
\hline \multirow{2}{*}{$\begin{array}{c}\text { Asset } \\
\text { percentile }\end{array}$} & \multicolumn{2}{|c|}{2001} & \multicolumn{2}{|c|}{1998} & \multicolumn{2}{|c|}{1995} & \multicolumn{2}{|c|}{1992} & \multicolumn{2}{|c|}{1989} \\
\hline & asset & debt & asset & debt & asset & debt & asset & debt & asset & debt \\
\hline$<25$ & 11.5 & 7.3 & 9.6 & 7.4 & 9.2 & 6.5 & 7.0 & 4.9 & 5.2 & 4.5 \\
\hline $25-50$ & 108.3 & 40.0 & 100.2 & 34.7 & 85.7 & 26.2 & 72.1 & 20.8 & 70.7 & 21.0 \\
\hline $50-60$ & 227.7 & 78.4 & 204.5 & 69.4 & 175.7 & 53.9 & 159.6 & 49.4 & 164.5 & 47.7 \\
\hline $60-70$ & 333.3 & 84.3 & 284.0 & 88.9 & 242.4 & 79.6 & 227.8 & 68.2 & 235.3 & 58.7 \\
\hline $70-80$ & 493.4 & 114.0 & 400.8 & 101.3 & 325.8 & 86.6 & 317.1 & 70.7 & 348.4 & 64.9 \\
\hline $80-90$ & 814.7 & 124.6 & 645.1 & 113.3 & 510.1 & 104.2 & 496.3 & 96.8 & 567.4 & 105.6 \\
\hline $90-99$ & $2,388.6$ & 190.3 & $1,781.9$ & 190.0 & $1,347.5$ & 138.6 & 1424.3 & 159.0 & 1546.8 & 126.8 \\
\hline Top 1 & $17,938.4$ & 463.4 & $14,516.2$ & 428.4 & $11,779.5$ & 366.3 & 9757.4 & 361.6 & 10549.3 & 289.4 \\
\hline average & 612.2 & 73.8 & 486.6 & 69.2 & 388.9 & 56.8 & 365.8 & 52.9 & 395.3 & 48.4 \\
\hline
\end{tabular}


Table 4. Effect on wealth from hypothetical price changes, by income groups

$\begin{array}{llllllllll}1989 & 1992 & 1995 & 1998 & 2001 & 2004 & 2007 & 2010 & 2013 & 2016\end{array}$

A. Hypothetical $10 \%$ decline in house prices

Families in bottom $50 \%$ of normal income

Avg. pct. of wealth lost from shock

Fraction losing $>10$ pct. of wealth

Avg. pct. of wealth lost from shock

Fraction losing $>10$ pct. of wealth

Avg. pct. of wealth lost from shock

Fraction losing $>10$ pct. of wealth

Avg. pct. of wealth lost from shock

Fraction losing $>10$ pct. of wealth

Avg. pct. of wealth lost from shock

Fraction losing $>10$ pct. of wealth

Avg. pct. of wealth lost from shock

Fraction losing $>10$ pct. of wealth

$\begin{array}{llllllllll}0.03 & 0.03 & 0.06 & 0.06 & 0.06 & 0.07 & 0.07 & 0.07 & 0.07 & 0.06 \\ 0.10 & 0.16 & 0.25 & 0.15 & 0.18 & 0.16 & 0.11 & 0.19 & 0.15 & 0.09 \\ 0.04 & 0.06 & 0.05 & 0.05 & 0.04 & 0.05 & 0.06 & 0.05 & 0.05 & 0.04 \\ 0.10 & 0.12 & 0.15 & 0.14 & 0.11 & 0.15 & 0.33 & 0.38 & 0.26 & 0.24 \\ 0.05 & 0.06 & 0.02 & 0.02 & 0.02 & 0.02 & 0.02 & 0.02 & 0.02 & 0.01 \\ 0.06 & 0.18 & 0.06 & 0.05 & 0.04 & 0.05 & 0.04 & 0.06 & 0.23 & 0.04\end{array}$

B. Hypothetical $10 \%$ decline in equity prices Families in the bottom $50 \%$ of normal income

\begin{tabular}{|c|c|c|c|c|c|c|c|c|c|}
\hline 0.04 & 0.05 & 0.02 & 0.02 & 0.03 & 0.02 & 0.02 & 0.03 & 0.02 & 0.03 \\
\hline 0.01 & 0.02 & 0.01 & 0.01 & 0.02 & 0.01 & 0.01 & 0.01 & 0.01 & 0.02 \\
\hline \multicolumn{10}{|c|}{ Families next $45 \%$ of normal income } \\
\hline 0.04 & 0.03 & 0.04 & 0.04 & 0.05 & 0.04 & 0.04 & 0.04 & 0.04 & 0.04 \\
\hline .01 & 0.02 & 0.02 & 0.04 & 0.04 & 0.03 & 0.04 & 0.04 & 0.04 & 0.04 \\
\hline \multicolumn{10}{|c|}{ Families in top $5 \%$ of normal income } \\
\hline .03 & 0.02 & 0.06 & 0.07 & 0.07 & 0.06 & 0.07 & 0.06 & 0.06 & 0.07 \\
\hline .01 & 0.01 & 0.04 & 0.05 & 0.05 & 0.05 & 0.05 & 0.05 & 0.05 & 0.05 \\
\hline
\end{tabular}

